\title{
Development of a reduction-sensitive diselenide- conjugated oligoethylenimine nanoparticulate system as a gene carrier
}

This article was published in the following Dove Press journal:

International Journal of Nanomedicine

24 July 2012

Number of times this article has been viewed

\author{
Gang Cheng',2 \\ Yiyan $\mathrm{He}^{1}$ \\ Li Xie' \\ Yu Nie' \\ Bin $\mathrm{He}^{\prime}$ \\ Zhirong Zhang ${ }^{2}$ \\ Zhongwei Gu'
}

'National Engineering Research Center for Biomaterials, ${ }^{2} \mathrm{Key}$ Laboratory of Drug Targeting and Drug Delivery Systems, West China School of Pharmacy, Sichuan University, Chengdu, Sichuan, People's Republic of China
Correspondence: Zhongwei Gu and Yu Nie

National Engineering Research Center for Biomaterials, Sichuan University, 29 Wangjiang Road, Chengdu, Sichuan 610064, People's Republic of China

Tel +8628 854l 0336

Fax +86 2885410653

Email zwgu@scu.edu.cn and

nie_yu@scu.edu.cn
Background: The reduction-sensitive cationic polymer is a promising nonviral carrier for gene delivery. Until now, disulfide bonds have been the only golden standard for its design. The aim of this research was to develop a novel reduction-responsive cationic polymer as a gene carrier.

Methods: Polycationic carriers were synthesized by addition of branched oligoethylenimine $800 \mathrm{Da}\left(\mathrm{OEI}_{800}\right)$ via an active ester containing diselenide bonds. Disulfide bonds cross-linked with $\mathrm{OEI}_{800}-\mathrm{SS}_{\mathrm{x}}$ and monoselenide bonds linked with $\mathrm{OEI}_{800}-\mathrm{Se}_{\mathrm{x}}$ were synthesized and compared. Their molecular weights and degradation properties were determined using gel permeation chromatography. Changes in particle size, morphology, and DNA binding were investigated by dynamic light scattering, transmission electron microscopy, and electrophoresis assay in a reduction environment. Cytotoxicity and transfection in vitro were evaluated in a murine melanoma cell line (B16F10) and a human cervical epithelial carcinoma cell line (HeLa), while intracellular degradation and dissociation with DNA were studied by confocal laser scanning microscopy with FITC-labeled $\mathrm{OEI}_{800}$ derivatives and Cy5-labeled DNA.

Results: Diselenide-conjugated $\mathrm{OEI}_{800}\left(\mathrm{OEI}_{800}-\mathrm{SeSe}_{\mathrm{x}}\right)$ polymer carriers of high molecular weight were successfully synthesized. After compacting with DNA, the $\mathrm{OEI}_{800}-\mathrm{SeSe}_{\mathrm{x}}$ polymers formed nanoparticles with an average size of $140 \mathrm{~nm}$ at an adequate $\mathrm{C} / \mathrm{P}$ ratio. $\mathrm{OEI}_{800}-\mathrm{SeSe}_{\mathrm{x}}$ showed reduction-responsive degradation properties similar to those of the $\mathrm{OEI}_{800}-\mathrm{SS}_{\mathrm{x}}$ via gel permeation chromatography, dynamic light scattering, and transmission electron microscopy. $\mathrm{OEI}_{800}-\mathrm{SeSe}_{\mathrm{x}}$ showed much lower cytotoxicity than $\mathrm{PEI}_{25 \mathrm{k}}$, and significantly higher transfection efficiency than $\mathrm{OEI}_{800}$ in both B16F10 and HeLa cells. Transfection of luciferase in the $\mathrm{OEI}_{800}-\mathrm{SeSe}_{\mathrm{x}}$ group was comparable with that of standard $\mathrm{PEI}_{25 \mathrm{k}}$ and traditional reduction-sensitive polymer $\mathrm{OEI}_{800}-\mathrm{SS}_{\mathrm{x}}$ groups. Furthermore, intracellular degradation of $\mathrm{OEI}_{800}-\mathrm{SeSe}_{\mathrm{x}}$ and dissociation with DNA were also confirmed by confocal laser scanning microscopy.

Conclusion: The $\mathrm{OEI}_{800}-\mathrm{SeSe}_{\mathrm{x}}$ obtained was able to bind plasmid DNA efficiently to yield nanosized particles and had reduction sensitivity which is as efficient as that for $\mathrm{OEI}_{800}-\mathrm{SS}_{\mathrm{x}}$. In vitro experiments confirmed its low cytotoxicity and high transfection ability. Diselenide bonds can be used as effective and novel reduction-sensitive linkages for gene delivery.

Keywords: diselenide, oligoethylenimine, reduction-sensitive, gene carriers

\section{Introduction}

Cationic polymer-mediated nonviral gene delivery has emerged as a viable alternative to viral vectors because of its ease of manufacturing, no limitation on DNA size, lesser inflammatory response, and lack of immunogenicity. ${ }^{1,2}$ However, cationic polymers are problematic in terms of the delivery process. Between the time when the complexes are assembled and when they are taken up by endosomes, the nucleic acids 
need to be well compacted within the cationic polymers to form complexes, thus requiring strong binding interactions to prevent gene degradation as a result of mechanical stress and enzymatic activity. ${ }^{3}$ On the other hand, after entry into the cell or endosomal escape, the complexes should dissociate to enable efficient gene release, which involves movement of DNA into the nucleus for transcription or targeting siRNA to mRNA for RNA interference. ${ }^{1,45}$ Moreover, high transfection efficiency is often associated with high toxicity of the vector. A typical example is polyethylenimine (PEI), which is one of the most effective nonviral gene delivery carriers due to its DNA-condensing capability, proton sponge effect for osmotic swelling, and physical rupture of the endosome..$^{6-10}$ PEI with its high molecular weight is necessary for effective gene transfection, but its presence also results in high cytotoxicity. In contrast, low molecular weight PEI has low toxicity but cannot condense DNA effectively and has poor transfection ability. ${ }^{11}$ Therefore, one approach is to design biodegradable polycations which allow efficient gene transfer and stimulusresponsive degradation into low molecular weight products with minimal toxicity.

Intracellular and extracellular environments differ in their $\mathrm{pH}$, enzymatic activity, and redox potential. For example, some intracellular compartments, such as late endosomes and lysosomes, are more acidic than normal physiological $\mathrm{pH} .{ }^{12,13}$ High matrix metalloproteinase expression is observed in tumor cells, ${ }^{14}$ and glutathione levels are higher intracellularly than extracellularly, ${ }^{15-17}$ being approximately 1000 -fold higher than the concentration in plasma. ${ }^{18}$ Furthermore, other intracellular reductive reagents, such as nicotinamide adenosine dinucleotide phosphate (NADPH), can change oxidative glutathione to reduced glutathione. ${ }^{19}$ These factors can be used as triggers for disassociation of polycation and gene payload. Various chemical linkers responsive to different triggers have been designed, including acetals, ${ }^{20-22}$ hydrazone bonds, ${ }^{23-26}$ esters, ${ }^{6}$ disulfides, ${ }^{27-33}$ and matrix metalloproteinase substrate peptide-containing linkers. ${ }^{14}$ Among them, disulfide bonds have been widely used as the only golden standard for reductive design in gene and drug delivery. ${ }^{27,29,34-37}$ After it was found that low molecular weight oligoethylenimine (OEI) cross-linked by dithiobis (succinimidylpropionate) or dimethyl $\cdot 3,3^{\prime}$-dithiobispropionimidate $\cdot 2 \mathrm{HCl}$ achieved highly efficient transfection in vitro and had lower cytotoxicity, ${ }^{34}$ much research attention has been focused on modification of different disulfide bonds containing linkers ${ }^{27-29,35}$ and effect of the molecular weight of cross-linked OEI. ${ }^{35}$

Inspired by the success of disulfide bonds, the selenium (Se) element listed in the same family as sulfur $(\mathrm{S})$ in the periodic table of elements has attracted attention. Diselenide bonds have also been considered as potential candidates for stimuli-sensitive design. As reported recently, diselenide bonds possess reductive biodegradable ability similar to that of disulfide bonds. ${ }^{19,40}$ Micelles formed by polymers containing diselenide bonds were quite stable under physiological conditions, but were sensitive to reductive stimuli. ${ }^{36}$ In addition, disulfide bonds were too fragile for the reductive environment, but can be cleaved by a reductive reagent in low concentration. ${ }^{35}$ This property is not beneficial for transfection in vivo, because the disulfide may be destroyed in the circulation, so the loaded genes cannot be delivered to their desired location.

In this study, diselenide bonds were introduced into a nonviral gene delivery system for the first time. The diselenide bonds were designed to be cleavable due to reduction, resulting in release of DNA inside the cell. Specifically, branched OEI $800 \mathrm{Da}\left(\mathrm{OEI}_{800}\right)$ was conjugated with diselenide bonds and with disulfide bonds, and their potential for reduction sensitivity was tested and compared.

\section{Materials and methods Materials}

Selenium powder and sodium borohydride $\left(\mathrm{NaBH}_{4}\right)$ were obtained from Kelong Chemical Company (Chengdu, China). Dulbecco's modified Eagle's medium (DMEM) and fetal bovine serum were obtained from Life Technologies Corporation (Gibco, Grand Island, NY), and 3-chloropropanoic acid, 3, 3'-disulfanediyldipropanoic acid (DSDPA), reduced glutathione, antibiotics (penicillin and streptomycin), branched polyethylenimine $25 \mathrm{kDa}\left(\mathrm{PEI}_{25 \mathrm{k}}\right)$, oligoethylenimine $\left(\mathrm{OEI}_{800}\right)$, and fluorescein isothiocyanate (FITC) were obtained from Sigma-Aldrich (Shanghai, China). N-hydroxysuccinimide (NHS) and 1-ethyl-3[3-(dimethylamino)-propyl] carbodiimide (EDC) were purchased from AstaTech Pharmaceutical (Chengdu, China). 1,4-dithiothreitol (DTT) and 3-(4, 5-dimethylthiazol-2-yl)-2, 5-diphenyltetrazolium bromide (MTT) were commercially available from Amresco (Solon, OH). Cell lysate and the luciferase reporter gene assay kit were purchased from Promega (Madison, WI). A bicinchoninic acid protein assay kit was purchased from Pierce (Rockford, IL). The DNA labeling kit, Label IT ${ }^{\circledR} \mathrm{Cy} 5$, was from Mirus Bio Corporation (Madison, WI), plasmid pGL3 (encoding Photinus pyralis luciferase under control of the SV40 enhancer/promoter) and enhanced green fluorescent protein encoding plasmid (pEGFP) was purified using the EndoFree plasmid kit from Qiagen (Hilden, Germany). All buffers were prepared in 
MilliQ ultrapure water and filtered $(0.22 \mu \mathrm{m})$ prior to use. All other chemicals were purchased from Sigma-Aldrich and used as received.

\section{Synthesis of DSeDPA and SeDPA}

3, 3'-Diselanediyldipropanoic acid (DSeDPA) was synthesized in the same manner as in previous studies, with some modifications. ${ }^{37,38}$ Selenium powder $(2.37 \mathrm{~g}, 30 \mathrm{mmol})$ in $10 \mathrm{~mL}$ of water was added to a three-necked flask under a nitrogen atmosphere. $\mathrm{NaBH}_{4}(2.27 \mathrm{~g}, 60 \mathrm{mmol})$ dissolved in $25 \mathrm{~mL}$ of cold $\mathrm{H}_{2} \mathrm{O}$ was syringed dropwise into the selenium suspension. The reaction mixture was stirred at $0^{\circ} \mathrm{C}$ and reacted until colorless for complete dissolution of the selenium powder. Another quantity of selenium powder $(2.37 \mathrm{~g}$, $30 \mathrm{mmol}$ ) was added, and the mixture was heated to $105^{\circ} \mathrm{C}$ for 20 minutes until reddish brown. 3-Chloropropanoic acid (6.5 g, $60 \mathrm{mmol})$ was dissolved in $15 \mathrm{~mL}$ of water, and its $\mathrm{pH}$ was adjusted to 8.0 with sodium carbonate $\left(\mathrm{Na}_{2} \mathrm{CO}_{3}\right)$. This was added to the reddish brown solution, with stirring overnight at room temperature under nitrogen. After another 4 hours of stirring and exposure to the atmosphere, the reaction mixture was filtered. The yellow supernatant was adjusted to $\mathrm{pH} 3-4$ using $1 \mathrm{~mol} / \mathrm{L} \mathrm{HCl}$ solution and extracted twice with ethyl acetate. The combined organic layers were washed with water, dried with anhydrous magnesium sulfate, filtered, and recrystallized from ethyl acetate to give a product of $5.29 \mathrm{~g}$ (a $58 \%$ yield). ${ }^{1} \mathrm{H}-\mathrm{NMR}$

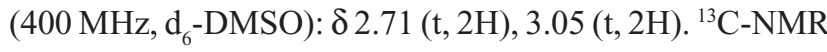
(d $\left.\mathrm{d}_{6} \mathrm{DMSO}\right): \delta 23.93,35.41,173.05 .{ }^{77} \mathrm{Se}-\mathrm{NMR}(400 \mathrm{MHz}$, $\mathrm{d}_{6}$-DMSO): $\delta$ 318.98. MS m/z: 302/306 $\left({ }^{78} \mathrm{Se} /{ }^{80} \mathrm{Se}\right.$ ) (shown in Supplementary Figure 1).

Synthesis of 3, 3'-selenodipropanoic acid (SeDPA) was similar to the process used for DSeDPA, but with a different ratio of selenium powder to $\mathrm{NaBH}_{4}$. Selenium powder (2.37 g, $30 \mathrm{mmol}$ ) was mixed with $\mathrm{NaBH}_{4}(2.27 \mathrm{~g}, 60 \mathrm{mmol})$ to obtain a colorless solution without adding another quantity of selenium powder, and then reacted with 3-chloropropanoic acid, with the same procedure followed after treatment. A final product of $3.85 \mathrm{~g}$ was obtained (a $57 \%$ yield). ${ }^{1} \mathrm{H}-\mathrm{NMR}$ (400 MHz, d $\mathrm{d}_{6}$ DMSO): $\delta 2.62$ (t, 2H), 2.69 (t, 2H). ${ }^{13} \mathrm{C}-\mathrm{NMR}$ (d $\mathrm{d}_{6}$-DMSO): $\delta 17.70,35.40,173.26$ (as shown in Supplementary Figure 2).

\section{Synthesis of disulfide, diselenide and monoselenide bonds for conjugation with OEI}

DSeDPA (0.365 g, $1.2 \mathrm{mmol})$, DSDPA (0.252 g, $1.2 \mathrm{mmol})$, or SeDPA (0.270 g, $1.2 \mathrm{mmol})$ and NHS
$(0.331 \mathrm{~g}, 2.88 \mathrm{mmol})$ dissolved in $5 \mathrm{~mL}$ of anhydrous tetrahydrofuran were added to a three-necked flask under nitrogen with magnetic stirring. EDC (0.445 g, $2.88 \mathrm{mmol})$ dissolved in $5 \mathrm{~mL}$ of anhydrous tetrahydrofuran was added dropwise into the mixture at $0^{\circ} \mathrm{C}$. The reaction mixture was stirred overnight at room temperature. After filtration, evaporation, and redissolution in $0.5 \mathrm{~mL}$ of anhydrous dimethyl sulfoxide, the active ester solution (DSeDPANHS, DSDPA-NHS or SeDPA-NHS) obtained was ready for further use.

Prior to cross-linking, $0.8 \mathrm{~g}$ ( $1 \mathrm{mmol})$ of oligoethylenimine $\left(\mathrm{OEI}_{800}\right)$ was dissolved in water with $\mathrm{pH}$ adjusted to 7.4 by $\mathrm{HCl}$ solution, and lyophilized. It was redissolved in $2 \mathrm{~mL}$ of dimethyl sulfoxide, and mixed with various active ester solutions (DSeDPA-NHS, DSDPA-NHS, or SeDPA-NHS) under nitrogen. The solution was stirred continuously for 2 days at $35^{\circ} \mathrm{C}$, and dialyzed against water using cellulose dialysis bags (molecular weight cutoff $7 \mathrm{kDa}$ ). The final products of $\mathrm{OEI}_{800}-\mathrm{SeSe}_{\mathrm{x}}, \mathrm{OEI}_{800}-\mathrm{SS}_{\mathrm{x}}$, and $\mathrm{OEI}_{800}-\mathrm{Se}_{\mathrm{x}}$ were obtained after lyophilization.

\section{NMR characterization}

NMR spectra for ${ }^{1} \mathrm{H},{ }^{13} \mathrm{C}$, and ${ }^{77} \mathrm{Se}$ were recorded on a Bruker Avance II NMR spectrometer at $400 \mathrm{MHz}$ using DMSO-d as solvents, with $0.5 \%$ tetramethylsilane as the internal standard.

\section{Molecular weight characterization}

The molecular weight of the products was determined by gel permeation chromatography (Waters, Milford, MA). A Waters 2690D high-pressure liquid chromatography system was equipped with Ultrahydrogel 1000 and 120 columns, as well as a refractive index detector. $\mathrm{NaCl}$ solution $0.1 \mathrm{M}$ with $\mathrm{pH}$ adjusted to 2.8 by $\mathrm{HCOOH}$ was used as the eluent at a flow rate of $1.0 \mathrm{~mL}$ per minute. The external and column temperatures were kept at $35^{\circ} \mathrm{C}$. Pullulan of a different molecular weight $(1 \mathrm{mg} / \mathrm{mL})$ was used as the standard for determination of the calibration curve.

\section{Measurement of degradation}

To measure degradation, $5 \mathrm{mg}$ of $\mathrm{OEI}_{800}-\mathrm{SeSe}_{\mathrm{x}}$ or $\mathrm{OEI}_{800}{ }^{-}$ $\mathrm{SS}_{\mathrm{x}}$ polymer dissolved in $0.9 \mathrm{~mL}$ of water was treated with $0.1 \mathrm{~mL}$ of glutathione $(1.0 \mathrm{~mol} / \mathrm{L})$, DTT $(1.0 \mathrm{~mol} / \mathrm{L})$, or $\mathrm{NaBH}_{4}(1.0 \mathrm{~mol} / \mathrm{L})$ at $37^{\circ} \mathrm{C}$ for 2 hours, respectively. $\mathrm{OEI}_{800}{ }^{-}$ $\mathrm{Se}_{\mathrm{x}}, \mathrm{PEI}_{25 \mathrm{k}}$, and $\mathrm{OEI}_{800}$ were used as controls. ${ }^{27}$ Degradation of $\mathrm{OEI}_{800}$ and other analogs cross-linked with disulfide and diselenide in reductive conditions was evaluated by gel permeation chromatography. 


\section{Complex formation, particle size, zeta potential, and morphology}

A cationic polymer solution in HEPES buffered glucose (20 mM HEPES and 5\% [w/v] glucose, $\mathrm{pH} 7.4$ ) was gently mixed with plasmid DNA HEPES buffered glucose $(100 \mu \mathrm{g} / \mathrm{mL})$ for preparation of complexes with different $\mathrm{C} / \mathrm{P}$ ratios (ie, weight ratios of cationic polymer to plasmid DNA). The nanoparticle suspension was incubated at room temperature for 20 minutes before use.

Particle sizes and zeta potentials of the complexes were characterized using a Zetasizer Nano ZS (Malvern Instruments, Worcestershire, UK). The incubated complexes (C/P 1.2, 3, or 6) were diluted to $1 \mathrm{~mL}$ with MilliQ water to a final plasmid DNA concentration of $3 \mu \mathrm{g} / \mathrm{mL}$. For measurement in a reductive environment, DTT or $\mathrm{NaBH}_{4}$ $25 \mathrm{mM}$ was added to the complexes and incubated at $37^{\circ} \mathrm{C}$ for 30 minutes prior to dilution. The morphology of the complexes was characterized by transmission electron microscopy. A drop of complex (C/P 6) suspension incubated with or without a reductive reagent was deposited on amorphous carbon-coated copper grids, dried, dyed using $2 \%(\mathrm{w} / \mathrm{w})$ phosphomolybdic acid, and detected using a JEOL JEM-100CX electron microscope (Tokyo, Japan).

\section{DNA binding determined by electrophoresis assay}

Suspensions of various complexes $\left(\mathrm{OEI}_{800}-\mathrm{SeSe}_{\mathrm{x}}, \mathrm{OEI}_{800^{-}}\right.$ $\mathrm{SS}_{\mathrm{x}}, \mathrm{OEI}_{800}-\mathrm{Se}_{\mathrm{x}}, \mathrm{PEI}_{25 \mathrm{k}}$, or $\mathrm{OEI}_{800}$ ) with different $\mathrm{C} / \mathrm{P}$ ratios (0.02-1.4) were loaded onto 1\% agarose gel. Electrophoresis was performed in Tris-acetate-EDTA buffer ( $\mathrm{pH} 8)$ running at $85 \mathrm{~V}$ for 40 minutes. The gel was stained with ethidium bromide and analyzed on an ultraviolet illuminator (BioRad, Hercules, CA) to visualize the location of the DNA bands. Compaction of the complexes under reduction conditions was evaluated after incubation with DTT at a final concentration of $25 \mathrm{mM}$ at $37^{\circ} \mathrm{C}$ for 30 minutes.

\section{Cell culture and cytotoxicity assay}

Murine melanoma cells (B16F10) and human cervical epithelial carcinoma cells (HeLa) obtained from the Shanghai Institute for Biological Science (Shanghai, China) were used for the cytotoxicity study. The B16F10 and HeLa cells were cultured in DMEM containing penicillin $100 \mathrm{U} / \mathrm{mL}$, streptomycin $100 \mu \mathrm{g} / \mathrm{mL}$, and fetal bovine serum $10 \%$ at $37^{\circ} \mathrm{C}$ in the presence of $5 \% \mathrm{CO}_{2}$.

Relative cell viability when incubated with the cationic polymer solution was determined by MTT assay. The B16F10 and HeLa cells were seeded into a 96-well tissue culture plate at a density of $8 \times 10^{3}$ cells per well in $100 \mu \mathrm{L}$ of DMEM. A designated amount of cationic polymer solution $\left(\mathrm{OEI}_{800}-\mathrm{SeSe}_{\mathrm{x}}, \mathrm{OEI}_{800}-\mathrm{SS}_{\mathrm{x}} \mathrm{OEI}_{800}-\mathrm{Se}_{\mathrm{x}}, \mathrm{PEI}_{25 \mathrm{k}}\right.$, and $\mathrm{OEI}_{800}$ at a final concentration of $5-50 \mu \mathrm{g} / \mathrm{mL}$ ) were added once cell confluence had reached $70 \%-80 \%$. After 24 hours of incubation, the cytotoxicity measurement was performed according to the usual laboratory protocol, and the ultraviolet value of the dissolved formazan crystals was recorded at $570 \mathrm{~nm}$ using a BioRad 550 microplate reader.

\section{Gene transfection of pEGFP and pGL3}

pEGFP and pGL3 was used to determine the transfection efficiency of the $\mathrm{OEI}_{800}$ derivatives. B16F10 and HeLa cells were seeded into 96-well plates at a density of $8 \times 10^{3}$ cells per well in $100 \mu \mathrm{L}$ of DMEM, and the cells were incubated overnight for attachment. Directly before transfection, the medium in each well was replaced with $100 \mu \mathrm{L}$ of fresh serum-free DMEM containing various amount of complexes (200 ng of plasmid DNA per well, C/P ratios 4-14). After 4 hours of incubation, the medium was replaced with $100 \mu \mathrm{L}$ of fresh serum-containing medium. Qualitative evaluation of pEGFP transfection was observed under a fluorescence microscope (Leica, Germany) after further incubation for 48 hours. Subsequently, the cells were washed with ice-cold phosphate-buffered solution, harvested, and placed in $1 \mathrm{~mL}$ of phosphate-buffered solution containing $10 \%$ fetal bovine serum. The percentage of transfected cells was determined by flow cytometry (BD FACSAria ${ }^{\mathrm{TM}}$ II, Franklin Lakes, $\mathrm{NJ}$ ), and was obtained by determining the statistics of cells fluorescing above the control level, where nontransfected cells were used as the control. Quantitative measurement using the luciferase assay was carried out after 24 hours of incubation according to the manufacturer's protocol. Relative light units were measured using a BioRad 550 microplate reader while total protein was measured using a bicinchoninic acid protein assay kit. Luciferase activity was expressed as relative fluorescence intensity per mg protein.

\section{Intracellular fate of nanoparticles by confocal laser scanning microscopy}

B16F10 cells were seeded at a density of $2 \times 10^{4}$ cells per well in a $35 \times 12 \mathrm{~mm}$ glass-bottomed chamber (NEST, Wuxi, China) the day before use. Cy5-labeled pEGFP DNA was prepared according to the DNA labeling kit (Label IT ${ }^{\circledR} \mathrm{Cy} 5$ ), while FITC-labeled cationic polymer was obtained via conjugation of FITC to the cationic polymer. ${ }^{39}$ Complexes containing $40 \%$ Cy5-labeled pEGFP and FITC-labeled cationic polymer with a $\mathrm{C} / \mathrm{P}$ ratio of 6 were added to serum-free fresh medium at 
$300 \mathrm{ng}$ of plasmid per chamber. At the desired incubation time points $(0.5,1,2,4$ and 8 hours $)$, the cells were washed twice with phosphate-buffered solution and observed with a confocal laser scanning microscope (Leica TCS SP5, Germany). The Cy5 fluorophore was excited at $543 \mathrm{~nm}$ and emission was detected using a $565-615 \mathrm{~nm}$ band pass filter, while FITC was excited at $495 \mathrm{~nm}$ and emission was detected using a 515-545 $\mathrm{nm}$ band pass filter. Data were analyzed using LAS AF Lite 2.3 software (Leica, Germany). ${ }^{40}$

\section{Data and statistical analysis}

Group data were reported as the mean \pm standard deviation. Differences between groups were analyzed by two-tailed heteroscedastic $t$-tests using Microsoft Excel 2010, and statistical significance was accepted at $P<0.05$.

\section{Results}

\section{Polymer synthesis and structural analysis}

The synthetic route of various cross-linked $\mathrm{OEI}_{800}$ (reductionresponsive and stable derivatives) is shown in Figure 1. Diselenide bonds cross-linked with $\mathrm{OEI}_{800}\left(\mathrm{OEI}_{800}-\mathrm{SeSe}_{\mathrm{x}}\right)$ was started by preparation of diselenide bonds containing the linker DSeDPA. The carboxyl group at the terminal end of DSeDPA was activated by NHS, using EDC as the dehydrolyzing agent in tetrahydrofuran. The active ester reacted with the primary amine group of the $\mathrm{OEI}_{800}$, resulting in diselenide bonds containing $\mathrm{OEI}_{800}-\mathrm{SeSe}_{\mathrm{x}}$. For controls, the corresponding stable analog $\mathrm{OEI}_{800}-\mathrm{Se}_{\mathrm{x}}$, and the standard reduction-responsive polymer $\mathrm{OEI}_{800}-\mathrm{SS}_{\mathrm{x}}$ containing disulfide bonds, were prepared (Figure 1). All the critical steps were confirmed by ${ }^{1} \mathrm{H}$ NMR. The chemical environment of the hydrogen close to selenium was different between DSeDP and SeDPA. The peak at 3.05 ppm reflects the signal of $\mathrm{CH}_{2}$ in DSeDPA, while the peak of $2.62 \mathrm{ppm}$ is assigned to the protons of $\mathrm{CH}_{2}$ in SeDPA. ${ }^{41}$ Accordingly, the peak of $\mathrm{CH}_{2}$ close to selenium in DSeDPA detected by ${ }^{13} \mathrm{C}-\mathrm{NMR}$ is 23.93 ppm, while that in SeDPA is 17.70 ppm. (Supplementary Figures 1 and 2).

\section{Molecular weight and degradation of diselenide, monoselenide, and disulfide bonds conjugated with $\mathrm{OEI}$}

The molecular weights of the reduction-sensitive $\mathrm{OEI}_{800^{-}}$ $\mathrm{SeSe}_{\mathrm{x}}$ and $\mathrm{OEI}_{800}-\mathrm{SS}_{\mathrm{x}}$ polymers and the stable $\mathrm{OEI}_{800}-\mathrm{Se}_{\mathrm{x}}$ polymer were detected by gel permeation chromatography in the absence or presence of the reduction substance (glutathione, DTT, or $\mathrm{NaBH}_{4}$, Table 1). Standard $\mathrm{PEI}_{25 \mathrm{k}}$ and $\mathrm{OEI}_{800}$ showed average molecular weights of $16 \mathrm{kDa}$ and $0.76 \mathrm{kDa}$, while the molecular weights of the cross-linked $\mathrm{OEI}_{800}-\mathrm{SS}_{\mathrm{x}}$ and $\mathrm{OEI}_{800}-\mathrm{SeSe}_{\mathrm{x}}$ polymers were about $12 \mathrm{kDa}$ and $18 \mathrm{kDa}$, respectively. $\mathrm{OEI}_{800}-\mathrm{Se}_{\mathrm{x}}$ was also cross-linked as a high molecular weight polymer of about $15 \mathrm{kDa}$. After incubation with the reductive reagents, the peak shift of the different polymers in gel permeation chromatography
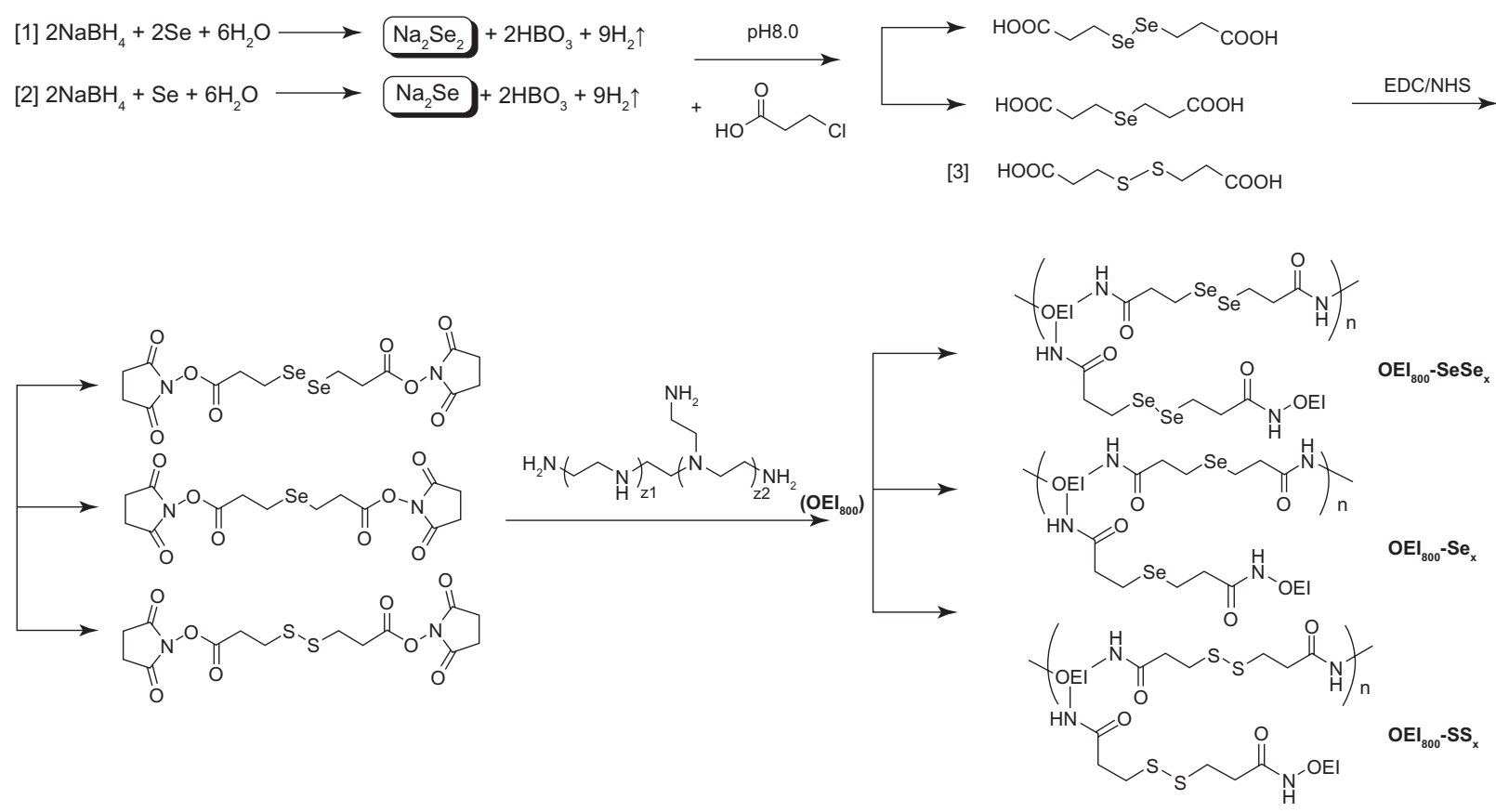

Figure I Synthetic schema for $\mathrm{OEI}_{800}-\mathrm{SeSe}_{x}$ ( I), OEI ${ }_{800}-\mathrm{Se}_{x}$ (2), and $\mathrm{OEI}_{800}-\mathrm{SS}_{x}$ (3).

Abbreviations: OEl, oligoethylenimine; NHS, N-hydroxysuccinimide; EDC, I-ethyl-3-[3-(dimethylamino)-propyl] carbodiimide. 
Table I Molecular weights of various polymers detected by gel permeation chromatography in the absence or presence of reduction reagents

\begin{tabular}{llll}
\hline Polymers & $\mathbf{M}_{w} / 10^{3} \mathbf{D a}$ & $\mathbf{M}_{\mathbf{n}} / \mathbf{0}^{3} \mathbf{D a}$ & PDI \\
\hline $\mathrm{OEI}_{800}-\mathrm{SS}_{x}$ & 12 & 3.9 & 3.1 \\
$\mathrm{OEI}_{800}-\mathrm{SS}_{x}+\mathrm{GSH}$ & 1.6 & 0.78 & 2.1 \\
$\mathrm{OEI}_{800}-\mathrm{SS}_{x}+\mathrm{DTT}$ & 0.99 & 0.75 & 1.3 \\
$\mathrm{OEI}_{800}-\mathrm{SeSe}_{x}$ & 18 & 5.3 & 3.4 \\
$\mathrm{OEI}_{800}-\mathrm{SeSe}_{x}+\mathrm{GSH}$ & 8.1 & 2.5 & 3.2 \\
$\mathrm{OEI}_{800}-\mathrm{SeSe}_{x}+\mathrm{DTT}$ & 3.9 & 2.6 & 1.5 \\
$\mathrm{OEI}_{800}-\mathrm{SeSe}_{x}+\mathrm{NaBH}_{4}$ & 1.4 & 0.79 & 1.8 \\
$\mathrm{OEI}_{800}-\mathrm{Se}_{x}$ & 15 & 5.7 & 2.8 \\
$\mathrm{OEI}_{800}-\mathrm{Se}_{x}+\mathrm{NaBH}_{4}$ & 15 & 5.8 & 2.7 \\
$\mathrm{PEI}_{25 \mathrm{k}}$ & 16 & 4.5 & 3.6 \\
$\mathrm{OEI}_{800}$ & 0.76 & 0.52 & 1.5 \\
\hline $\mathrm{Abb}$ & &
\end{tabular}

Abbreviations: DTT, I,4-dithiothreitol; $M_{w}$, weight-average molecular weight; $M_{n}$, number-average molecular weight; PDI, polydispersity index; OEI, oligoethylenimine;

became diversified (Supplementary Figure 3). The peaks of $\mathrm{OEI}_{800}-\mathrm{SS}_{\mathrm{x}}$ and $\mathrm{OEI}_{800}-\mathrm{SeSe}_{\mathrm{x}}$ obviously shifted to a longer time point, indicating a decrease in molecular weight due to degradation, while the molecular weight of $\mathrm{OEI}_{800}-\mathrm{Se}_{\mathrm{x}}$ remained constant. It was interesting that the molecular PEI, polyethylenimine; GSH, glutathione.

weight of $\mathrm{OEI}_{800}-\mathrm{SS}_{\mathrm{x}}$ decreased to $1.6 \mathrm{kDa}$ after treatment with glutathione, but to $0.99 \mathrm{kDa}$ after DTT treatment, which is very close to the molecular weight of $\mathrm{OEI}_{800}(0.76 \mathrm{kDa})$. The molecular weight of $\mathrm{OEI}_{800}-\mathrm{SeSe}_{\mathrm{x}}$ reduced to 8.1, 3.9, and $1.4 \mathrm{kDa}$ after being incubated with glutathione, DTT and $\mathrm{NaBH}_{4}$, respectively.

\section{Characterization of particle size, zeta potential, and morphology}

Dynamic light scattering measurements were used to examine the hydrodynamic particle size of the complexes (Figure 2A). The polymers of $\mathrm{PEI}_{25 \mathrm{k}}, \mathrm{OEI}_{800}-\mathrm{SeSe}_{\mathrm{x}}, \mathrm{OEI}_{800}-\mathrm{SS}_{\mathrm{x}}$, and $\mathrm{OEI}_{800}-\mathrm{Se}_{\mathrm{x}}$ were able to condense plasmid DNA in the form of complexes (C/P 1.2 for $\mathrm{PEI}_{25 \mathrm{k}}$, and C/P 1.2-6 for $\mathrm{OEI}_{800}$ derivatives), with an approximate diameter of $140-250 \mathrm{~nm}$ and a narrow distribution. The size of the complexes with $\mathrm{OEI}_{800}$ derivatives depended on the $\mathrm{C} / \mathrm{P}$ ratio. For instance, the sizes of the $\mathrm{OEI}_{800}-\mathrm{SeSe}_{\mathrm{x}}$ complexes decreased from $250 \mathrm{~nm}$, to $190 \mathrm{~nm}$, to about $140 \mathrm{~nm}$, as the C/P increased from 1.2 , to 3 , to 6 . In contrast, the complexes formed by $\mathrm{OEI}_{800}$ and plasmid DNA tended to aggregate or disperse
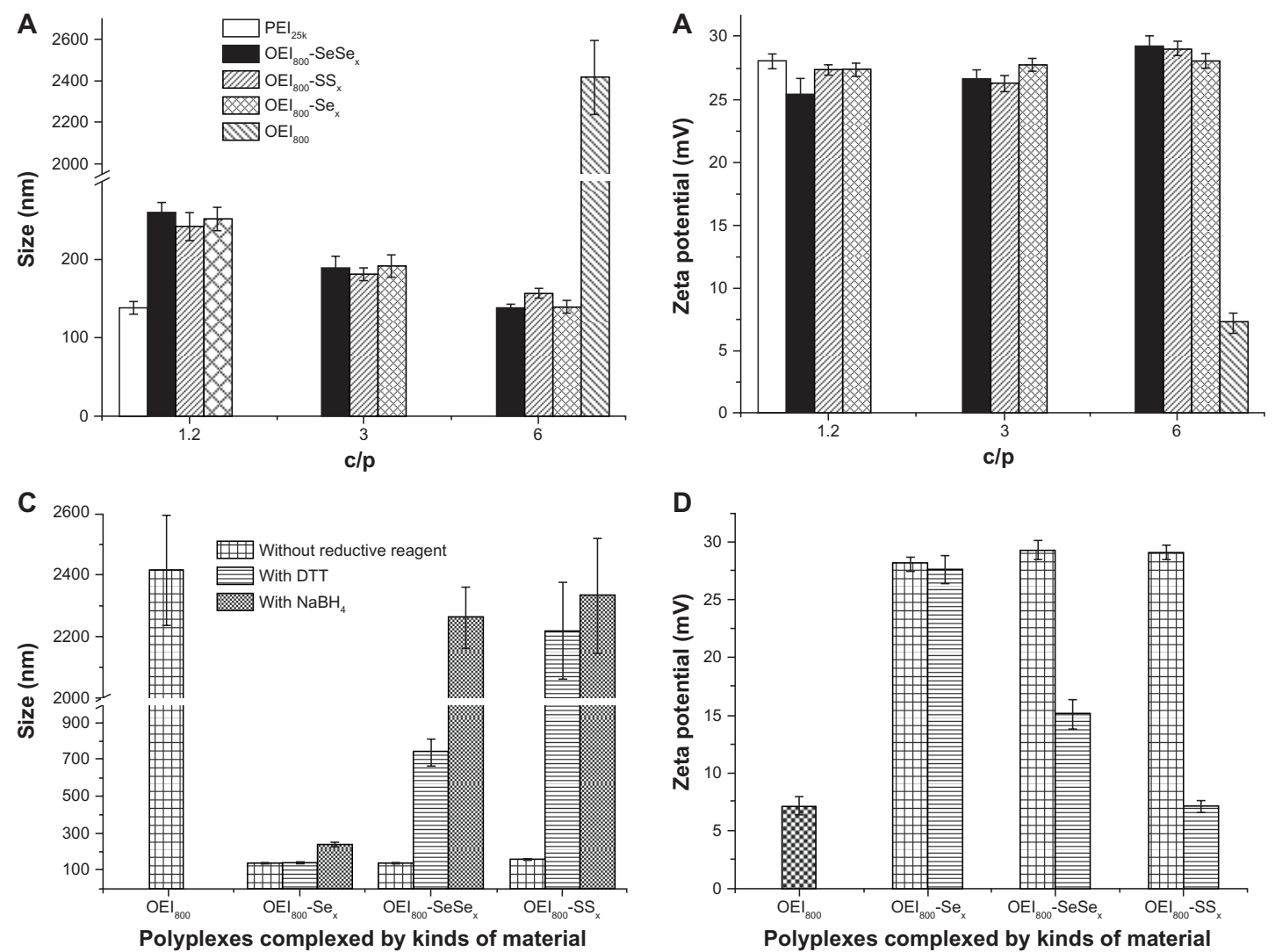

Figure 2 Sizes and zeta potentials of various complexes determined by Zetasizer $\mathrm{Nano}_{\mathrm{ZS}}$. (A) Sizes of complexes composed of $\mathrm{PEI}_{25 \mathrm{k}}, \mathrm{OEI}_{800}$, or OEI ${ }_{800}$ derivatives and genes at different $\mathrm{C} / \mathrm{P}$ ratios, (B) zeta potentials of complexes composed of $\mathrm{PEI}_{25 \mathrm{k}^{\prime}}, \mathrm{OEI}_{800}$ or $\mathrm{OEI}_{800}$ derivatives and genes at different $\mathrm{C} / \mathrm{P}$ ratios, $(\mathbf{C})$ changes in size with or without the reductive reagent (C/P 6), and (D) zeta potential changes with or without the reductive reagent $(C / P 6, n=3)$.

Abbreviations: DTT, I,4-dithiothreitol; OEI, oligoethylenimine; PEI, polyethylenimine. 
at a diameter over $2000 \mathrm{~nm}$, even at a high C/P ratio of 6 . Accordingly, the well compacted nanoparticles composed of high molecular weight polycations $\left(\mathrm{PEI}_{25 \mathrm{k}}\right.$ and $\mathrm{OEI}_{800}$ derivatives) and DNA were all positively charged, with about $+27 \mathrm{mV}$ zeta potential, while that of low molecular weight $\mathrm{OEI}_{800}$ complexes was only about $+7 \mathrm{mV}$ (Figure $2 \mathrm{~B}$ ). After being treated with different reductive reagents, the size of the $\mathrm{OEI}_{800}-\mathrm{SeSe}_{\mathrm{x}}, \mathrm{OEI}_{800}-\mathrm{SS}_{\mathrm{x}}$, and OEI-Se $e_{\mathrm{x}}$ complexes was detected at an appropriate $\mathrm{C} / \mathrm{P}$ of 6 (Figure 2C). The average diameter of $\mathrm{OEI}_{800}-\mathrm{SeSe}_{\mathrm{x}} / \mathrm{DNA}$ complexes with $\mathrm{NaBH}_{4}$ and $\mathrm{OEI}_{800}-\mathrm{SS}_{\mathrm{x}} / \mathrm{DNA}$ complexes in DTT and $\mathrm{NaBH}_{4}$ was obviously increased to over $2200 \mathrm{~nm}$, and the size of $\mathrm{OEI}_{800^{-}}$ $\mathrm{SeSe}_{\mathrm{x}} / \mathrm{DNA}$ (C/P 6) treated with DTT increased to about $740 \mathrm{~nm}$. As controls, the stable analog $\mathrm{OEI}_{800}-\mathrm{Se}_{\mathrm{x}} / \mathrm{DNA}$ (C/P 6) complexes showed no obvious changes after being treated with reductive reagents. Changes in the zeta potential were also observed after treatment with DTT (Figure 2D). The mean surface charge of well compacted nanoparticles containing disulfide bonds and diselenide bonds reduced to approximately $15 \mathrm{mV}$ and $7 \mathrm{mV}$, respectively, while no change was detectable in the $\mathrm{OEI}_{800}-\mathrm{Se}_{\mathrm{x}}$ group $(P>0.05)$.

In addition, the morphology of the complexes investigated by transmission electron microscopy was in agreement with the size measurement by dynamic light scattering (Figure 3). $\mathrm{PEI}_{25 \mathrm{k}}, \mathrm{OEI}_{800}-\mathrm{SeSe}_{\mathrm{x}}$, and $\mathrm{OEI}_{800}-\mathrm{SS}_{\mathrm{x}}$ could compact plasmid DNA to form nanoparticles at an appropriate $\mathrm{C} / \mathrm{P}$ ratio. All diameters of the $\mathrm{PEI}_{25 \mathrm{k}} / \mathrm{DNA}(\mathrm{C} / \mathrm{P} 1.2)$, $\mathrm{OEI}_{800}-\mathrm{SeSe}_{\mathrm{x}} / \mathrm{DNA}(\mathrm{C} / \mathrm{P} 6)$, and $\mathrm{OEI}_{800}-\mathrm{SS}_{\mathrm{x}} / \mathrm{DNA}$ (C/P 6) complexes were less than $200 \mathrm{~nm}$, whereas samples of DNA condensed by $\mathrm{OEI}_{800}$ was partly aggregated and dispersed.
After treatment with $\mathrm{NaBH}_{4}$, the diameter of $\mathrm{OEI}_{800}-\mathrm{SeSe}_{\mathrm{x}}$ / DNA increased to more than $400 \mathrm{~nm}$, which was similar to what phenomena happened to $\mathrm{OEI}_{800}-\mathrm{SS}_{\mathrm{x}} / \mathrm{DNA}$ upon treatment with DTT. It was obvious that the $\mathrm{OEI}_{800}-\mathrm{SeSe}_{\mathrm{x}} /$ DNA and $\mathrm{OEI}_{800}-\mathrm{SS}_{\mathrm{x}} / \mathrm{DNA}$ complexes became looser after incubation with the reductive substance, indicating that both $\mathrm{OEI}_{800}-\mathrm{SeSe}_{\mathrm{x}}$ and $\mathrm{OEI}_{800}-\mathrm{SS}_{\mathrm{x}}$ had reduction-sensitive ability and would degrade to low molecular weight OEI in the reductive environment.

\section{DNA binding ability in presence and absence of reduction reagents}

The gel retardation assay verified that all the cationic polymers could retard DNA at an appropriate $\mathrm{C} / \mathrm{P}$ ratio, and as the polymer concentration increased, their capacity to integrate with plasmid DNA was enhanced (Figure 4). Polycations containing high molecular weight polymers, including $\mathrm{OEI}_{800}-\mathrm{SS}_{\mathrm{x}}$ (Figure 4A), $\mathrm{OEI}_{800}-\mathrm{SeSe}_{\mathrm{x}}$ (Figure 4B), $\mathrm{OEI}_{800}-\mathrm{Se}_{\mathrm{x}}$ (Figure 4C), and $\mathrm{PEI}_{25 \mathrm{k}}$ (Figure 4E), could completely retard DNA migration at a $\mathrm{C} / \mathrm{P}$ ratio of 0.4 , while $\mathrm{OEI}_{800}$ formed stable complexes with DNA only at $\mathrm{C} / \mathrm{P}$ ratios higher than 0.6 . This indicated that cross-linked $\mathrm{OEI}_{800}$ can condense plasmid DNA at $\mathrm{C} / \mathrm{P}$ ratios lower than that of the original monomer. After incubation with DTT, the reduction-responsive polymers of $\mathrm{OEI}_{800}-\mathrm{SeSe}_{\mathrm{x}}$ and $\mathrm{OEI}_{800}{ }^{-}$ $\mathrm{SS}_{\mathrm{x}}$ released part of their DNA at $\mathrm{C} / \mathrm{P}$ ratios of 0.4 and 0.5 , respectively, returning to a condensation ability similar to that of $\mathrm{OEI}_{800}$. On the other hand, the corresponding stable analog $\left(\mathrm{OEI}_{800}-\mathrm{Se}_{\mathrm{x}}\right)$ showed no detectable changes after treatment with DTT.

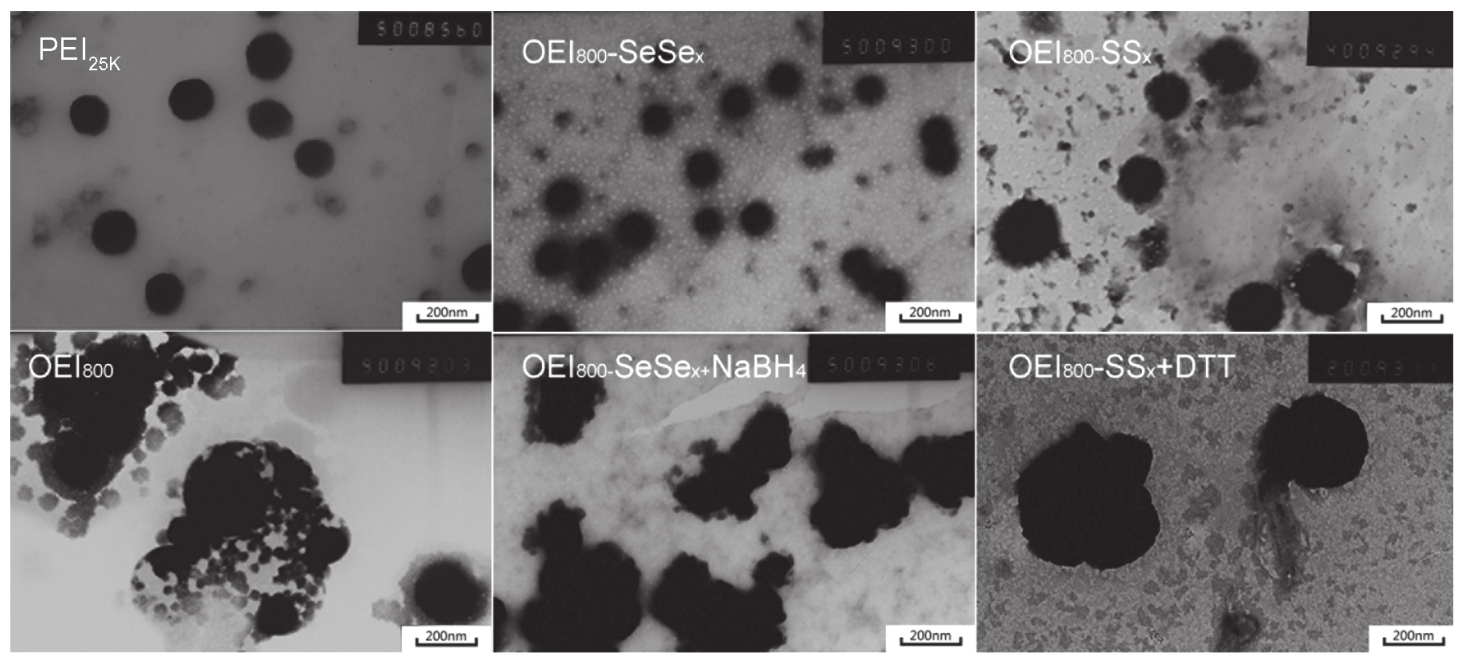

Figure 3 Transmission electron microscopy results for $\mathrm{PEI}_{25 \mathrm{k}^{\prime}}, \mathrm{OEI}_{800}$, and $\mathrm{OEI}_{800}$-derived complexes dropped onto amorphous carbon-coated copper grids, dried, and dyed using phosphomolybdic acid.

Note: $\mathrm{Bar}=200 \mathrm{~nm}$.

Abbreviations: DTT, I,4-dithiothreitol; OEI, oligoethylenimine; PEI, polyethylenimine. 

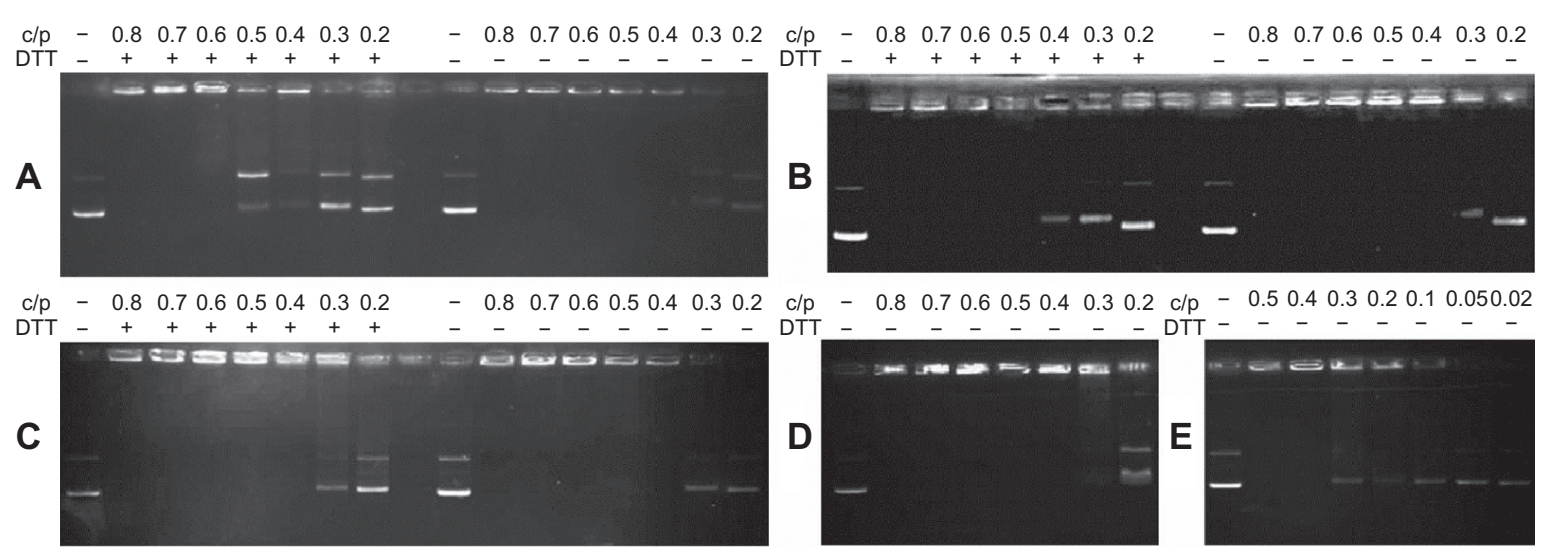

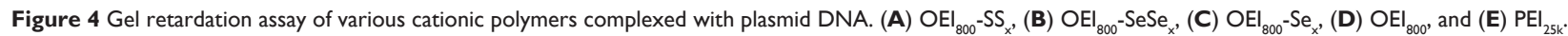
Notes: Polymers and plasmid DNA were mixed at various mass ratios and incubated at $37^{\circ} \mathrm{C}$ for 30 minutes with or without DTT. The mixed suspension was subsequently applied to the agarose gel and electrophoresed at $85 \mathrm{~V}$ for 40 minutes.

Abbreviations: DTT, I,4-dithiothreitol; OEI, oligoethylenimine; PEI, polyethylenimine.

\section{Cytotoxicity of DNA-free copolymers}

The cytotoxicity of the $\mathrm{OEI}_{800}$ derivatives in $\mathrm{B} 16 \mathrm{~F} 10$ and HeLa cells was tested by MTT assay, with $\mathrm{OEI}_{800}$ and $\mathrm{PEI}_{25 \mathrm{k}}$ as controls (Figure 5). $\mathrm{PEI}_{25 \mathrm{k}}$ was the most toxic polymer, while cells treated with $\mathrm{OEI}_{800}$ retained more than $90 \%$ of their metabolic activity. Both reductionsensitive bonds of cross-linked copolymers $\left(\mathrm{OEI}_{800}-\mathrm{SeSe}_{\mathrm{x}}\right.$ and $\mathrm{OEI}_{800}-\mathrm{SS}_{\mathrm{x}}$ ) showed lower cytotoxicity than $\mathrm{PEI}_{25 \mathrm{k}}$ and stable bonds of cross-linked polymers $\left(\mathrm{OEI}_{800}-\mathrm{Se}_{\mathrm{x}}\right)$ in B16F10 cells (Figure 5A), with the same trend observed in HeLa (Figure 5B). For instance, at the same concentration of $50 \mu \mathrm{g} / \mathrm{mL}$, only $40 \%-50 \%$ viability was found after treatment with $\mathrm{PEI}_{25 \mathrm{k}}$ and $\mathrm{OEI}_{800}-\mathrm{Se}_{\mathrm{x}}$ in B16F10 cells, while that for $\mathrm{OEI}_{800}-\mathrm{SeSe}_{\mathrm{x}}$ and $\mathrm{OEI}_{800}-\mathrm{SS}_{\mathrm{x}}$ remained at $76 \%$ and $52 \%$, respectively.

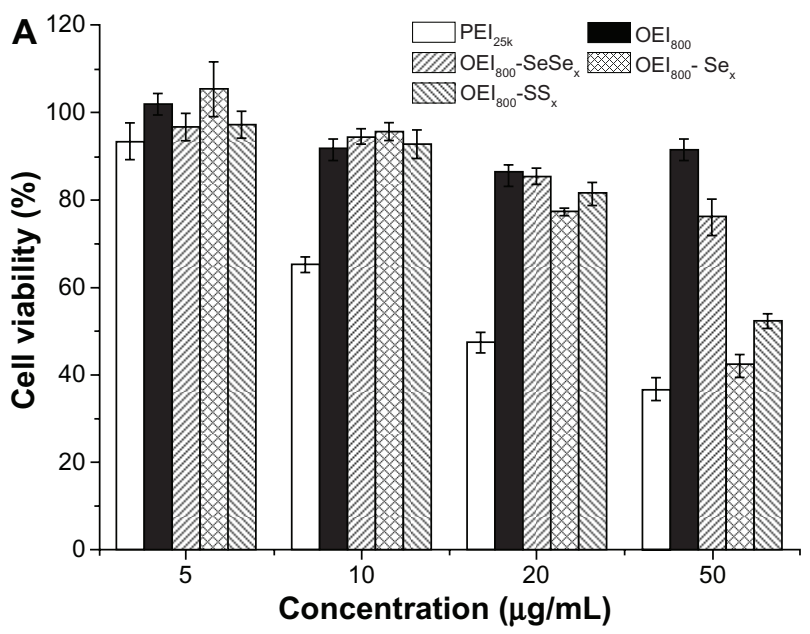

\section{EGFP and luciferase reporter gene expression in carcinoma cells}

The transfection activity of $\mathrm{OEI}_{800}$-derived nanoparticles, including $\mathrm{OEI}_{800}-\mathrm{SeSe}_{\mathrm{x}}, \mathrm{OEI}_{800}-\mathrm{SS}_{\mathrm{x}}$, and $\mathrm{OEI}_{800}-\mathrm{Se}_{\mathrm{x}}$, was evaluated in B16F10 (Figure 6A) and HeLa (Figure 6B) cells using pEGFP (Figure 7) and pGL3 (Figure 6). All of the $\mathrm{OEI}_{800}$-derived nanoparticles had significantly higher transfection ability than that of $\mathrm{OEI}_{800}$ alone. Incubation of cells with $\mathrm{OEI}_{800}-\mathrm{SeSe}_{\mathrm{x}}$ and $\mathrm{OEI}_{800}-\mathrm{SS}_{\mathrm{x}}$ nanoparticles resulted in slightly higher luciferase expression than that for $\mathrm{PEI}_{25 \mathrm{k}}$ in B16F10. For example, pGL3 transfection of the reductionsensitive nanoparticles $\left(\mathrm{OEI}_{800}-\mathrm{SeSe}_{\mathrm{x}}\right.$ and $\left.\mathrm{OEI}_{800}-\mathrm{SS}_{\mathrm{x}}\right)$ was $3.3 \times 10^{9}$ and $5.8 \times 10^{9}$ relative light units $/ \mathrm{mg}$ protein at the optimum $\mathrm{C} / \mathrm{P}$ ratio in $\mathrm{B} 16 \mathrm{~F} 10$ cells, respectively, which was four orders of magnitude higher than that for the $\mathrm{OEI}_{800}$

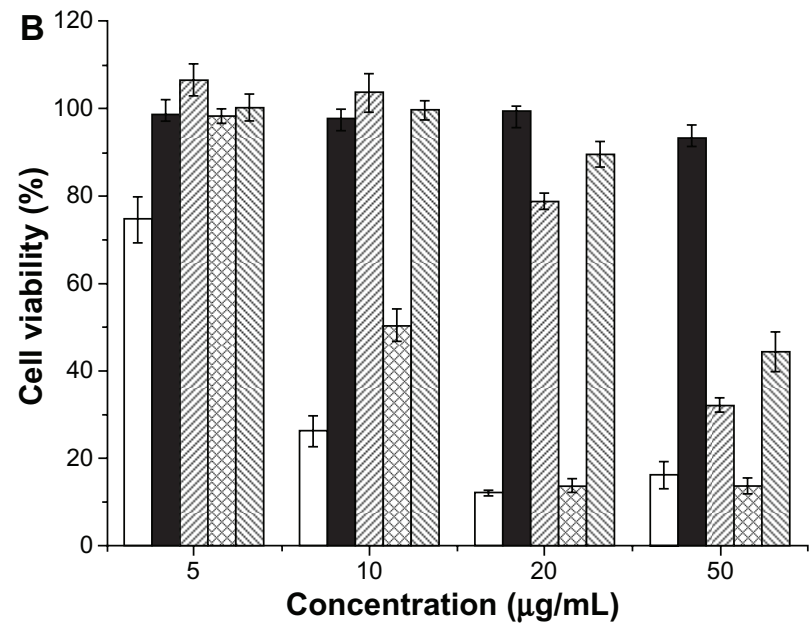

Figure 5 Cytotoxicity assays of the $\mathrm{OEI}_{800}$ derivatives, $\mathrm{OEI}_{800}$, and $\mathrm{PEI}_{25 \mathrm{k}}$ in $(\mathbf{A}) \mathrm{BI} 6 \mathrm{FIO}$ and (B) HeLa cells. Note: The polymers were incubated with the cells for 24 hours $(n=4)$.

Abbreviations: OEl, oligoethylenimine; PEl, polyethylenimine. 

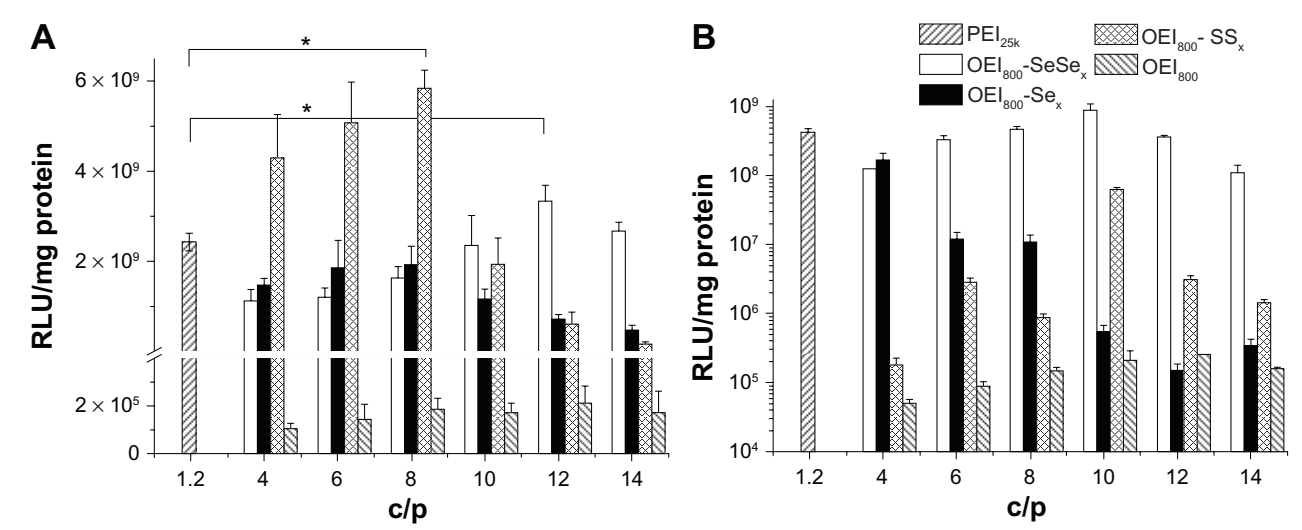

Figure 6 Luciferase transfection of the polycation-pGL3 complexes in (A) BI6FIO cells and (B) HeLa cells.

Notes: All the complexes were prepared in HEPES buffered glucose, and $200 \mathrm{ng}$ of pGL3 per well was used for the 96 -well tissue culture plate. The data show the average for experiments performed at least three times $(n=3$, *P $<0.05)$.

Abbreviations: OEI, oligoethylenimine; PEI, polyethylenimine; RLU, relative light units.

nanoparticles (only about $1.0 \times 10^{5}$ relative light units $/ \mathrm{mg}$ protein). In addition, transfection of $\mathrm{OEI}_{800^{-}}-\mathrm{SeSe}_{\mathrm{x}}$ and $\mathrm{OEI}_{800^{-}}$ $\mathrm{SS}_{\mathrm{x}}$ nanoparticles was up to about 1.5 -fold and 2.0 -fold higher compared with that of $\mathrm{PEI}_{25 \mathrm{k}}\left(\mathrm{C} / \mathrm{P} 1.2,2.4 \times 10^{9}\right.$ relative light units/mg protein, $P<0.05$ ). Interestingly, transfection of $\mathrm{OEI}_{800}-\mathrm{SeSe}_{\mathrm{x}}$ was higher than that of $\mathrm{OEI}_{800}-\mathrm{SS}_{\mathrm{x}}$ at $\mathrm{C} / \mathrm{P} \geq 10$, and was lower than $\mathrm{OEI}_{800}-\mathrm{SS}_{\mathrm{x}}$ at $\mathrm{C} / \mathrm{P} \leq 8$ in $\mathrm{B} 16 \mathrm{~F} 10$ cells. For example, luciferase expression in the $\mathrm{OEI}_{800}-\mathrm{SeSe}_{\mathrm{x}}$ group was up to approximately 5 -fold higher compared with that in the $\mathrm{OEI}_{800}-\mathrm{SS}_{\mathrm{x}}$ group at C/P 12 (Figure 6A). On the other hand, transfection of $\mathrm{OEI}_{800}-\mathrm{SeSe}_{\mathrm{x}}$ was higher than that of $\mathrm{OEI}_{800}-\mathrm{SS}_{\mathrm{x}}$ in $\mathrm{HeLa}$ cells at all $\mathrm{C} / \mathrm{P}$ ratios in the experiment. In particular, it was three orders of magnitude higher than that of $\mathrm{OEI}_{800}-\mathrm{SS}_{\mathrm{x}}$ at $\mathrm{C} / \mathrm{P} 4$ (Figure 6B).

The results of qualitative studies on transfection of plasmid DNA encoding EGFP with various $\mathrm{OEI}_{800}$-derived nanoparticles were consistent with those for luciferase expression, which was visualized with a fluorescent microscope in B16F10 cells. After 48 hours of transfection, cells incubated with $\mathrm{OEI}_{800}$ derivatives $\left(\mathrm{OEI}_{800}-\mathrm{SeSe}_{\mathrm{x}}, \mathrm{OEI}_{800}-\mathrm{SS}_{\mathrm{x}}\right.$, $\mathrm{OEI}_{800}-\mathrm{Se}_{\mathrm{x}}$ ) and $\mathrm{PEI}_{25 \mathrm{k}}$ nanoparticles showed more bright green fluorescent spots, especially at a $\mathrm{C} / \mathrm{P}$ ratio of 8 , for $\mathrm{OEI}_{800}-\mathrm{SeSe}_{\mathrm{x}}$ or $\mathrm{OEI}_{800}-\mathrm{SS}_{\mathrm{x}}$, and a C/P ratio of 4 for $\mathrm{OEI}_{800}-\mathrm{Se}_{\mathrm{x}}$ (Figure 7), indicating more expression of green fluorescent protein. In addition, there were almost no fluorescence spots in the $\mathrm{OEI}_{800}-\mathrm{SS}_{\mathrm{x}}$ group at $\mathrm{C} / \mathrm{P} 14$, while a large number of fluorescent spots was found in the $\mathrm{OEI}_{800}-\mathrm{SeSe}_{\mathrm{x}}$ group. The percentage of transfected cells detected by flow cytometry showed the same trend as the results for fluorescent microscopy (Figure 8 and Supplementary Figure 4).

\section{Intracellular investigation of labeled DNA and cationic polymers}

Dual-labeled nanoparticles were prepared using Cy5-labeled DNA and FITC-labeled cationic polymers. Interaction between the polymers, DNA, and cells was monitored by confocal laser scanning microscopy. For ease of graphical representation, images of $\mathrm{B} 16 \mathrm{~F} 10$ cells incubated with different types of nanoparticles (including $\mathrm{PEI}_{25 \mathrm{k}}, \mathrm{OEI}_{800}-\mathrm{SeSe}_{\mathrm{x}}$ and $\mathrm{OEI}_{800}-\mathrm{SS}_{\mathrm{x}}$ ) for 4 hours and 8 hours are shown (Figure 9). At 4 hours, approximately $80 \%$ of the nanoparticles assembled around the cell membrane, while more fluorescent spots
Control
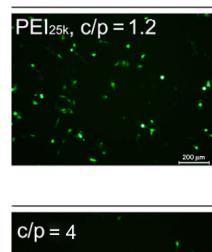
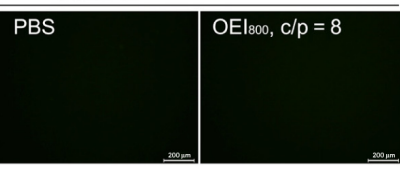

OEl $800-\mathrm{SeSe}_{x}$

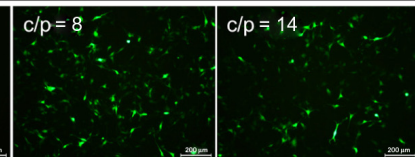

OEl $800-S_{x}$

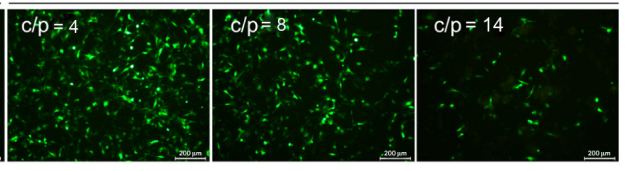

OEl $800-S_{x}$

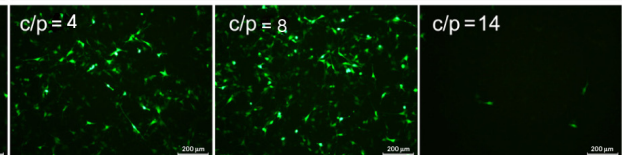

Figure 7 In vitro transfection efficiency of the complexes of pEGFP with $\mathrm{OEI}_{800}-\mathrm{SeSe}_{x}, \mathrm{OEI}_{800}-\mathrm{Se}_{x^{\prime}}, \mathrm{OEI}_{800}-\mathrm{SS}_{x^{\prime}}, \mathrm{PEI}_{25 \mathrm{k}}$, and $\mathrm{OEI} \mathrm{B}_{800}$ in $\mathrm{BI} 6 \mathrm{FIO}$ cell lines at 48 hours. Note: $\mathrm{Bar}=200 \mu \mathrm{m}$.

Abbreviations: OEl, oligoethylenimine; PEI, polyethylenimine; pEGFP, enhanced green fluorescent protein encoding plasmid. 


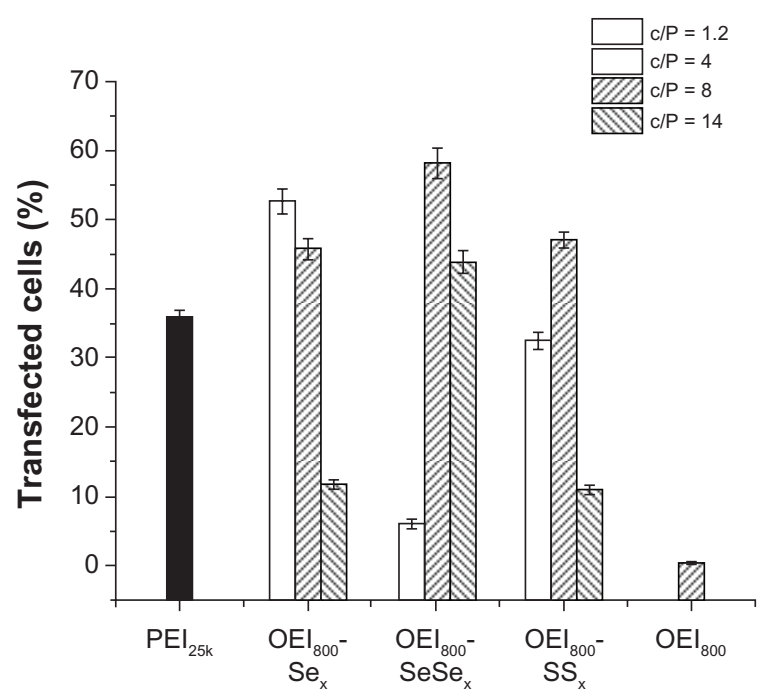

Figure 8 Percentages of transfected cells for the complexes of pEGFP with $\mathrm{OEI}_{800^{-}}$ $\mathrm{SeSe}_{x}, \mathrm{OEI}_{800}-\mathrm{Se}_{x}, \mathrm{OEI}_{800}-\mathrm{SS}_{x}, \mathrm{PEI}_{25 \mathrm{k}}$, and $\mathrm{OEI}_{800}$ quantified by flow cytometry analysis in BI6FIO cells at 48 hours

Note: $\mathrm{n}=3$.

Abbreviations: OEI, oligoethylenimine; PEI, polyethylenimine; pEGFP, enhanced green fluorescent protein encoding plasmid.

located inside the cells after 8 hours of incubation. This shows that nanoparticles tend to enter the cytoplasm from the surface of cell along with the time. Before 4 hours, good compaction of the polycations and negatively charged DNA is indicated by the orange color, caused by overlay of colors from the green FITC and red Cy5. Importantly, at the 8-hour time point, the intracellular fluorescent dots in the $\mathrm{PEI}_{25 \mathrm{k}}$ group remained orange, but more dots in the $\mathrm{OEI}_{800}-\mathrm{SS}_{\mathrm{x}}$ and
$\mathrm{OEI}_{800}-\mathrm{SeSe}_{\mathrm{x}}$ groups were red. These changes were not seen on the membrane of cells in the $\mathrm{OEI}_{800}$-derived group.

\section{Discussion}

For decades, disulfide bonds have been intensively explored in drug and gene delivery. No other reduction-sensitive chemical linkage has been developed that could work as a substitution for it until now. Recently, diselenide bonds have been reported for the dual redox-sensitive design, ${ }^{36,42}$ but their utility has not been extended to gene carrier systems. In the current study, diselenide bonds for cross-linked $\mathrm{OEI}_{800}$ were synthesized in order to construct reduction-sensitive gene carriers with high transfection ability and low cytotoxicity. According to the design (Figure 10), cross-linked $\mathrm{OEI}_{800}-\mathrm{SeSe}_{\mathrm{x}}$ with a high molecular weight should efficiently compact with DNA to form cationic complexes. After entering an environment of higher redox potential, such as the cytoplasm, the diselenide bonds would be expected to be cleaved, breaking into subunits of $\mathrm{OEI}_{800}$ and leading to dissociation of the complexes. This would help to move DNA into the nucleus for transcription, and keep a balance between high transfection ability and low cytotoxicity on delivery.

In order to achieve cross-linking of diselenide bonds with $\mathrm{OEI}_{800}, \mathrm{DSeDPA}$ linkage was undertaken. The corresponding reduction-stable linker (SeDPA) was prepared by a similar method and was used as a negative control (Figure 1). DSeDPA and SeDPA were synthesized by reacting 3-chloropropanoic acid with $\mathrm{Na}_{2} \mathrm{Se}_{2}$ and $\mathrm{Na}_{2} \mathrm{Se}$, respectively.

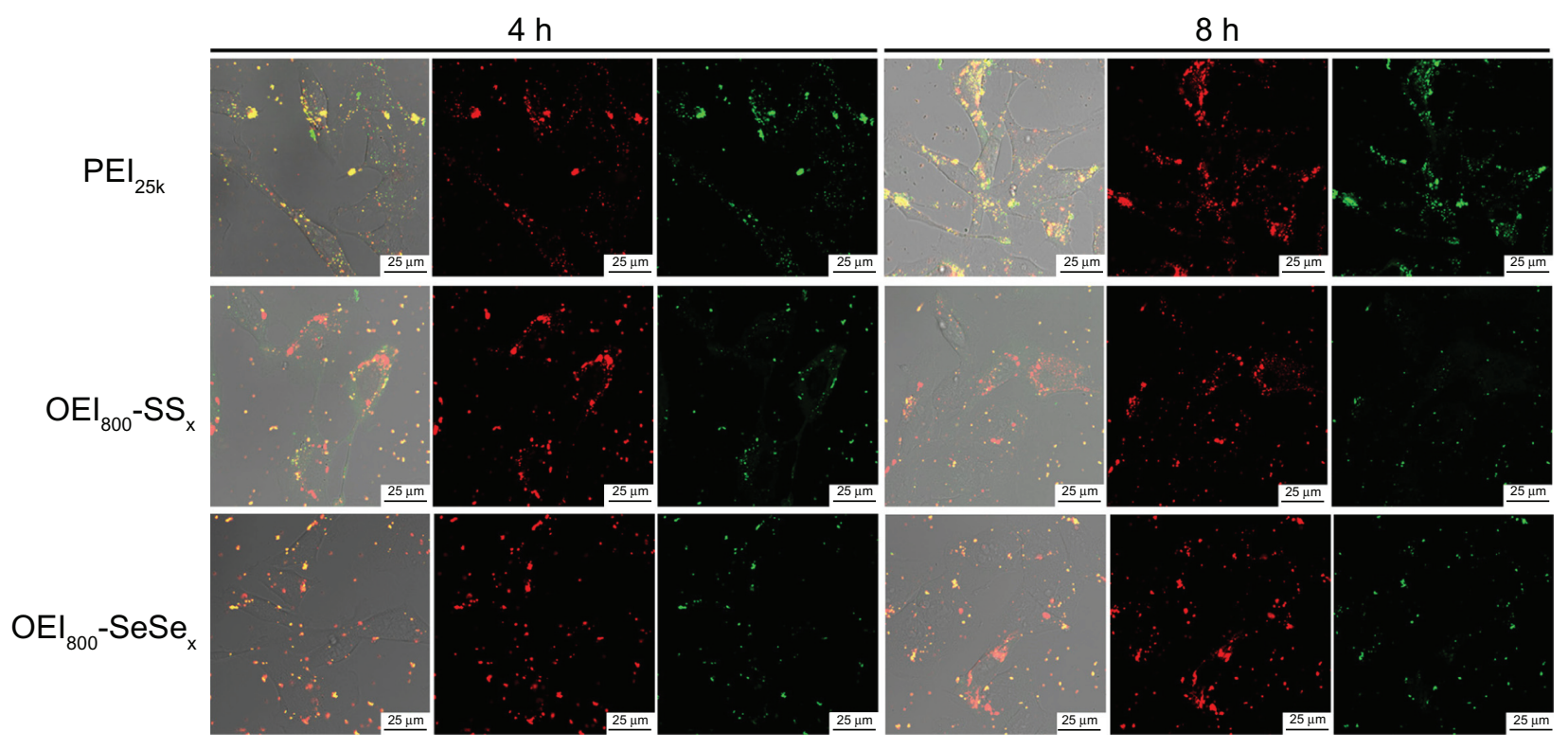

Figure 9 Labeled DNA and cationic polymer for intracellular investigation in BI6FI0 cells. Red dots: Cy5-labeled DNA; green dots: FITC-labeled PEI or OEI ${ }_{800}$ derivatives. Note: $\mathrm{Bar}=25 \mu \mathrm{m}$.

Abbreviations: OEl, oligoethylenimine; PEl, polyethylenimine. 


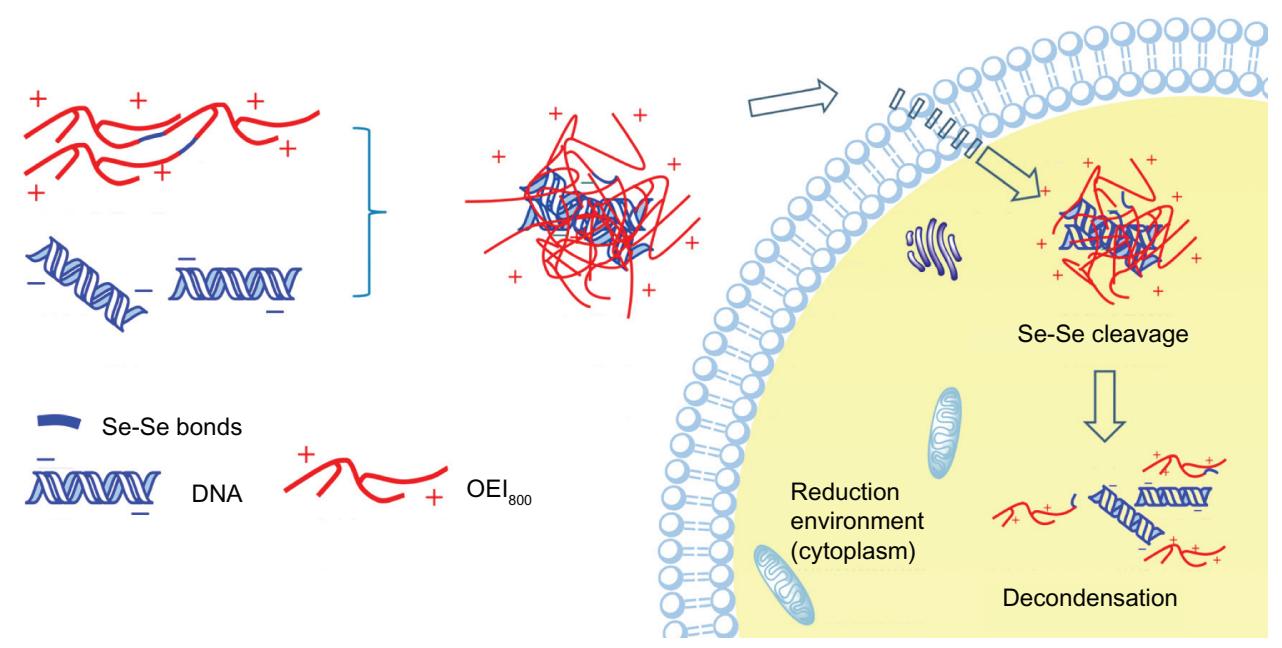

Figure 10 Schematic illustration of decondensation of reduction-sensitive complexes in the intracellular environment.

The key to obtaining distinct $\mathrm{Na}_{2} \mathrm{Se}_{2}$ and $\mathrm{Na}_{2} \mathrm{Se}$ depended on different ratios of $\mathrm{NaBH}_{4}$ to selenium powder. When the molecular ratio of $\mathrm{NaBH}_{4}$ to selenium was 2, colorless $\mathrm{Na}_{2} \mathrm{Se}$ was given as the product, and reddish brown $\mathrm{Na}_{2} \mathrm{Se}_{2}$ was obtained at a ratio of $1 .{ }^{38}$ To avoid $\mathrm{H}_{2} \mathrm{Se}_{2}$ gas production as a side reaction, the $\mathrm{pH}$ of 3-chloropropanoic acid should be adjusted to 8.0. After reacting with 3-chloropropanoic acid overnight, $\mathrm{Na}_{2} \mathrm{Se}_{2}$ or $\mathrm{Na}_{2} \mathrm{Se}$ residues should be oxidized to selenium by exposure to the atmosphere for easy purification via filtration. Unreacted DSeDPA and SeDPA was removed by adjusting the $\mathrm{pH}$ of the supernatant for formation of a precipitate at $\mathrm{pH} 3-4 .{ }^{38}$ In view of the instability of diselenide bonds in an alkaline environment $(\mathrm{pH}>10),{ }^{43}$ the alkaline $\mathrm{OEI}_{800}$ solution should be neutralized to $\mathrm{pH} 7.4$ prior to cross-linking. At the cross-linking step, the concentration of $\mathrm{OEI}_{800}$ must be controlled, and is significantly related to the molecular weight of the final product. ${ }^{35}$ The higher molecular weight of the cross-linked $\mathrm{OEI}_{800}$ would be obtained, because the intermolecular reaction occurs easily at high $\mathrm{OEI}_{800}$ concentrations. In our synthesis reaction, the $\mathrm{OEI}_{800}$ concentration was $25 \%(\mathrm{w} / \mathrm{w})$.

According to molecular weight measurement by gel permeation chromatography, $\mathrm{OEI}_{800}-\mathrm{SeSe}_{\mathrm{x}}$ (about $18 \mathrm{kDa}$ ), $\mathrm{OEI}_{800}-\mathrm{SS}_{\mathrm{x}}$ (about $12 \mathrm{kDa}$ ), and $\mathrm{OEI}_{800}-\mathrm{Se}_{\mathrm{x}}$ (about $16 \mathrm{kDa}$ ) of high molecular weight were synthesized successfully. It was seen that only the $\mathrm{OEI}_{800}-\mathrm{SeSe}_{\mathrm{x}}$ and $\mathrm{OEI}_{800}-\mathrm{SS}_{\mathrm{x}}$ degraded after being treated with reductive reagents (Table 1 and Supplementary Figure 3). Interestingly, $\mathrm{OEI}_{800}-\mathrm{SS}_{\mathrm{x}}$ could degrade to $\mathrm{OEI}_{800}$ after treatment with DTT or glutathione. However, under the same conditions, the $\mathrm{OEI}_{800}-\mathrm{SeSe}_{\mathrm{x}}$ did not degrade completely, and would degrade to smaller $\mathrm{OEI}_{800}$ pieces only when treated with a much more efficient reductive reagent, ie, $\mathrm{NaBH}_{4}$. After complexing with DNA, dynamic light scattering measurements of the complexes showed concordant results (Figure 2). The size of particles formed by $\mathrm{OEI}_{800}-\mathrm{SS}_{\mathrm{x}}$ increased to over $2000 \mathrm{~nm}$ after incubation with DTT, while that of the $\mathrm{OEI}_{800}-\mathrm{SeSe}_{\mathrm{x}}$ group increased to approximately $740 \mathrm{~nm}$. The increased size in the $\mathrm{OEI}_{800}-\mathrm{SS}_{\mathrm{x}}$ and $\mathrm{OEI}_{800}-\mathrm{SeSe}_{\mathrm{x}}$ groups reached over $2000 \mathrm{~nm}$ only after treatment with $\mathrm{NaBH}_{4}$. In addition, the reductionsensitive ability of the diselenide bonds was demonstrated by characterization of morphology (Figure 3 and Table 1). $\mathrm{OEI}_{800}-\mathrm{SeSe}_{\mathrm{x}}$ could complex with plasmid DNA efficiently to form nanosized particles, and the results of transmission electron microscopy indicated the mean diameter of the particles to be less than $200 \mathrm{~nm}$. OEI $\mathrm{O}_{800}-\mathrm{SeSe}_{\mathrm{x}}$ nanoparticles in $\mathrm{NaBH}_{4}$ showed similar swelling with $\mathrm{OEI}_{800}-\mathrm{SS}_{\mathrm{x}}$ in DTT. After treatment with reduction reagents, changes detected by transmission electron microscopy were not as obvious as the changes determined by dynamic light scattering. This difference was due to the fact that the dynamic light scattering method gives the hydration diameter rather than the actual (dry) diameter detected by transmission electron microscopy. ${ }^{44}$ The changes in molecular weight, particle size, and morphology all confirmed that the disulfide and diselenide bonds in $\mathrm{OEI}_{800}-\mathrm{SeSe}_{\mathrm{x}}$ and $\mathrm{OEI}_{800}-\mathrm{SS}_{\mathrm{x}}$ were cleavable in a reductive environment, and that cleavage of the diselenide bonds needs a more efficient reducible reagent. The likely reason for this is that diselenide bonds are more stable than disulfide bonds, with a lower redox potential. ${ }^{19}$ This property is beneficial for transfection in vivo because disulfide bonds may be cleaved by glutathione at the concentrations present in blood, while diselenide bonds remain stable. ${ }^{18,35}$ 
In the gel retardation assay, the ability of $\mathrm{OEI}_{800}-\mathrm{SeSe}_{\mathrm{x}}$ and $\mathrm{OEI}_{800}-\mathrm{SS}_{\mathrm{x}}$ to complex with the DNA decreased after treatment with DTT, which implies a reduction-sensitive ability for diselenide bonds and that the reductive reaction between DTT and $\mathrm{OEI}_{800}-\mathrm{SeSe}_{\mathrm{x}}$ was already efficient enough for release of DNA (Figure 4). Accordingly, the MTT assay of $\mathrm{OEI}_{800}-\mathrm{SeSe}_{\mathrm{x}}$ and $\mathrm{OEI}_{800}-\mathrm{SS}_{\mathrm{x}}$ showed similarly lower toxicity in comparison with stable $\mathrm{OEI}_{800}-\mathrm{Se}_{\mathrm{x}}$ and $\mathrm{PEI}_{25 \mathrm{k}}$ complexes (Figure 5). Although the diselenide bonds were much more stable than disulfide bonds, in the cytotoxicity assay, there was not only glutathione present as a reductive reagent in the cytoplasm but also high amounts of NADPH. As reported elsewhere, selenoglutathione can oxidize the common biological cofactor NADPH, and reacts strongly with glutathione reductase, which is an NADPH-dependent enzyme. ${ }^{19}$ Therefore, diselenide bonds can be efficiently cleaved in a cell reduction environment and have the same reduction-sensitive ability as disulfide bonds.

In the in vitro transfection assay, $\mathrm{OEI}_{800}-\mathrm{SeSe}_{\mathrm{x}}$ had much higher transfection ability than others based on $\mathrm{OEI}_{800}$, and even similar or higher transfection ability than $\mathrm{PEI}_{25 \mathrm{k}}$ (Figure 6). Compared with $\mathrm{OEI}_{800}, \mathrm{OEI}_{800}-\mathrm{SeSe}_{\mathrm{x}}$ with its high molecular weight possessed a better ability to condense plasmid DNA, and could form tight nanoparticles and endocytose easily. It was hypothesized that the reductionsensitive disulfide and diselenide bonds could be cleaved in the intracellular environment, triggered by glutathione or $\mathrm{NADPH},{ }^{19}$ and the $\mathrm{OEI}_{800}-\mathrm{SeSe}_{\mathrm{x}}$ and $\mathrm{OEI}_{800}-\mathrm{SS}_{\mathrm{x}}$ degraded to pieces of $\mathrm{OEI}_{800}$, which led to release of plasmid DNA to get high transfection ability and lower cytotoxicity. These results are in agreement with those of other studies of $\mathrm{OEI}_{800}$ cross-linked by degradable bonds. ${ }^{6,28,29}$ In addition, the optimum $\mathrm{C} / \mathrm{P}$ of cross-linked $\mathrm{OEI}_{800}$ for transfection was found to be higher than for $\mathrm{PEI}_{25 \mathrm{k}}$, which may be because the OEI content was lower in cross-linked $\mathrm{OEI}_{800}$ or because of the increased hydrophobicity. ${ }^{6}$ At a high $\mathrm{C} / \mathrm{P}$ ratio $(\mathrm{C} / \mathrm{P}$ $\geq 10$ in quantitative transfection and $\mathrm{C} / \mathrm{P} 14$ in qualitative transfection), transfection of $\mathrm{OEI}_{800}-\mathrm{SeSe}_{\mathrm{x}}$ was higher than that of $\mathrm{OEI}_{800}-\mathrm{SS}_{\mathrm{x}}$ in B16F10 cells (Figures 6A and 7), which might have been because of the cytotoxicity of $\mathrm{OEI}_{800}-\mathrm{SS}_{\mathrm{x}}$ is higher than that of $\mathrm{OEI}_{800}-\mathrm{SeSe}_{\mathrm{x}}$ at high concentrations (Figure 5A). The difference in effect between $\mathrm{OEI}_{800}-\mathrm{SeSe}_{\mathrm{x}}$ and $\mathrm{OEI}_{800}-\mathrm{SS}_{\mathrm{x}}$ in $\mathrm{B} 16 \mathrm{~F} 10$ and HeLa cells indicates the cell-dependent reduction sensitivity of diselenide. Based on these results, the diselenide bond-conjugated OEI is more suitable as a reduction-sensitive gene carrier than disulfide bond-conjugated OEI. Moreover, they had small differences in stability, ${ }^{19}$ which might affect transfection ability. Further studies will be carried out on the sensitivity of diselenide and disulfide under physiological conditions and the timedependence of response to a reducing agent. Like disulfide bonds, diselenide bonds can be used widely in smart drugs and for gene delivery.

In order to explore the intracellular fate of the nanoparticles, three kinds of cationic polymer-plasmid DNA complexes were investigated. It was obvious that they could be endocytosed easily, and many red or orange dots were observed in the cytoplasm (Figure 9). More red dots were observed in the groups containing reduction bonds and more orange dots were seen in the groups containing stable bonds. The number of red fluorescent dots increased with the passage of time in the $\mathrm{OEI}_{800}-\mathrm{SeSe}_{\mathrm{x}}$ and $\mathrm{OEI}_{800}-\mathrm{SS}_{\mathrm{x}}$ groups, while no significant change was observed in the $\mathrm{PEI}_{25 \mathrm{k}}$ group during the experiment. The $\mathrm{PEI}_{25 \mathrm{k}}$ group contained stable bonds which could condense DNA tightly and showed orange fluorescent dots which were the overlay of the red from $\mathrm{Cy} 5$ and the green from FITC. For the $\mathrm{OEI}_{800}-\mathrm{SeSe}_{\mathrm{x}}$ and $\mathrm{OEI}_{800}-\mathrm{SS}_{\mathrm{x}}$ groups, which contained reduction-sensitive bonds, cleavage of the disulfide bonds or diselenide bonds would cause parts of the FTIC to be released from the nanoparticles, and more red fluorescent dots were observed with the passage of time. This phenomenon implies that diselenide and disulfide bonds are reduction-sensitive.

\section{Conclusion}

This study describes the design and synthesis of diselenide bonds cross-linked to $\mathrm{OEI}_{800}$ for use as reduction-sensitive gene carriers. The results show that diselenide-containing $\mathrm{OEI}_{800}-\mathrm{SeSe}_{\mathrm{x}}$ was able to bind plasmid DNA efficiently to yield nanosized particles and had the same reduction sensitivity as $\mathrm{OEI}_{800}-\mathrm{SS}_{\mathrm{x}}$. In vitro experiments demonstrated that the reducible $\mathrm{OEI}_{800}-\mathrm{SeSe}_{\mathrm{x}}$ and $\mathrm{OEI}_{800}-\mathrm{SS}_{\mathrm{x}}$ had much lower cytotoxicity and higher transfection activity compared with the nondegradable $\mathrm{PEI}_{25 \mathrm{k}}$ control. The transfection ability of $\mathrm{OEI}_{800}-\mathrm{SeSe}_{\mathrm{x}}$ was higher than that of $\mathrm{OEI}_{800}-\mathrm{SS}_{\mathrm{x}}$ in $\mathrm{B} 16 \mathrm{~F} 10$ cells at a $\mathrm{C} / \mathrm{P}$ ratio $\geq 10$, while the transfection ability of $\mathrm{OEI}_{800}-\mathrm{SeSe}_{\mathrm{x}}$ was higher than that of $\mathrm{OEI}_{800}-\mathrm{SS}_{\mathrm{x}}$ in HeLa cells at all $\mathrm{C} / \mathrm{P}$ ratios used in this experiment. The reduction sensitivity of diselenide was cell-dependent. The results of our confocal laser scanning microscopy experiments demonstrated directly that both $\mathrm{OEI}_{800}-\mathrm{SeSe}_{\mathrm{x}}$ and $\mathrm{OEI}_{800}-\mathrm{SS}_{\mathrm{x}}$ could be cleavable in a cell-reductive environment. Our results imply that OEI conjugated with diselenide bonds is suitable for use as a reduction-sensitive gene carrier. 


\section{Acknowledgments}

This study was supported by the National 973 programs, 2011CB606206, National Natural Science Foundation of China $(51133004,81000657,50830105,31070849)$, Ministry of Science and Technology (2010DFA 51550), Research Fund for the Doctoral Program of Higher Education of China (20100181120075), and International Cooperative Foundation of Sichuan Province (2009HH0001)

\section{Disclosure}

The authors report no conflicts of interest in this work.

\section{References}

1. Mintzer MA, Simanek EE. Nonviral vectors for gene delivery. Chem Rev. 2008;109(2):259-302.

2. Sun YX, Xiao W, Cheng SX, Zhang XZ, Zhuo RX. Synthesis of (Dex-HMDI)-g-PEIs as effective and low cytotoxic nonviral gene vectors. J Control Release. 2008;128(2):171-178.

3. Nie Y, Zhang ZR, Duan YR. Combined use of polycationic peptide and biodegradable macromolecular polymer as a novel gene delivery system: a preliminary study. Drug Deliv. 2006;13(6):441-446.

4. Wang XL, Nguyen T, Gillespie D, Jensen R, Lu ZR. A multifunctional and reversibly polymerizable carrier for efficient siRNA delivery. Biomaterials. 2008;29(1):15-22.

5. Pouton CW, Seymour LW. Key issues in non-viral gene delivery. $A d v$ Drug Deliv Rev. 2001;46(1-3):187-203.

6. Russ V, Elfberg H, Thoma C, Kloeckner J, Ogris M, Wagner E. Novel degradable oligoethylenimine acrylate ester-based pseudodendrimers for in vitro and in vivo gene transfer. Gene Ther. 2008;15(1): $18-29$.

7. Bonnet ME, Erbacher P, Bolcato-Bellemin AL. Systemic delivery of DNA or siRNA mediated by linear polyethylenimine (L-PEI) does not induce an inflammatory response. Pharm Res. 2008;25(12):2972-2982.

8. Coll JL, Chollet P, Brambilla E, Desplanques D, Behr JP, Favrot M. In vivo delivery to tumors of DNA complexed with linear polyethylenimine. Hum Gene Ther. 1999;10(10):1659-1666.

9. Wightman L, Kircheis R, Rössler V, et al. Different behavior of branched and linear polyethylenimine for gene delivery in vitro and in vivo. J Gene Med. 2001;3(4):362-372.

10. Intra J, Salem AK. Characterization of the transgene expression generated by branched and linear polyethylenimine-plasmid DNA nanoparticles in vitro and after intraperitoneal injection in vivo. J Control Release. 2008;130(2):129-138.

11. Wen Y, Pan S, Luo X, Zhang X, Zhang W, Feng M. A biodegradable low molecular weight polyethylenimine derivative as low toxicity and efficient gene vector. Bioconjug Chem. 2009;20(2):322-332.

12. Breunig M, Bauer S, Goepferich A. Polymers and nanoparticles: intelligent tools for intracellular targeting? Eur J Pharm Biopharm. 2008;68(1):112-128.

13. Yang SR, Lee HJ, Kim JD. Histidine-conjugated poly(amino acid) derivatives for the novel endosomolytic delivery carrier of doxorubicin. J Control Release. 2006;114(1):60-68.

14. Hatakeyama H, Akita H, Kogure K, et al. Development of a novel systemic gene delivery system for cancer therapy with a tumor-specific cleavable PEG-lipid. Gene Ther. 2007;14(1):68-77.

15. Yeh CC, Hou MF, Wu SH, et al. A study of glutathione status in the blood and tissues of patients with breast cancer. Cell Biochem Funct 2006;24(6):555-559.

16. Schafer FQ, Buettner GR. Redox environment of the cell as viewed through the redox state of the glutathione disulfide/glutathione couple. Free Radic Biol Med. 2001;30(11):1191-1212.
17. Verma A, Simard JM, Worrall JWE, Rotello VM. Tunable reactivation of nanoparticle-inhibited $\beta$-galactosidase by glutathione at intracellular concentrations. J Am Chem Soc. 2004;126(43): 13987-13991.

18. Jones DP, Carlson JL, Samiec PS, et al. Glutathione measurement in human plasma evaluation of sample collection, storage and derivatization conditions for analysis of dansyl derivatives by HPLC. Clin Chim Acta. 1998;275(2):175-184.

19. Beld J, Woycechowsky KJ, Hilvert D. Selenoglutathione: efficient oxidative protein folding by a diselenide. Biochemistry. 2007;46(18):5382-5390.

20. Chen W, Meng F, Cheng R, Zhong Z. pH-sensitive degradable polymersomes for triggered release of anticancer drugs: a comparative study with micelles. J Control Release. 2010;142(1):40-46.

21. Liu R, Zhang Y, Zhao X, Agarwal A, Mueller LJ, Feng P. $\mathrm{pH}$-responsive nanogated ensemble based on gold-capped mesoporous silica through an acid-labile acetal linker. JAm Chem Soc. 2010;132(5): 1500-1501.

22. Chan Y, Bulmus V, Zareie MH, Byrne FL, Barner L, Kavallaris M. Acid-cleavable polymeric core-shell particles for delivery of hydrophobic drugs. J Control Release. 2006;115(2):197-207.

23. Prabaharan M, Grailer JJ, Pilla S, Steeber DA, Gong SQ. Amphiphilic multi-arm-block copolymer conjugated with doxorubicin via $\mathrm{pH}$-sensitive hydrazone bond for tumor-targeted drug delivery. Biomaterials. 2009;30(29):5757-5766.

24. Fella C, Walker GF, Ogris M, Wagner E. Amine-reactive pyridylhydrazone-based $\mathrm{PEG}$ reagents for $\mathrm{pH}$-reversible PEI polyplex shielding. Eur J Pharm Sci. 2008;34(4-5):309-320.

25. Braunová A, Pechar M, Ulbrich K. Biodegradable high-molecularweight multiblock polymers based on poly(ethylene glycol) for drug delivery. J Control Release. 2008;132(3):e20-e22.

26. Sawant RM, Hurley JP, Salmaso S, et al. "Smart" drug delivery systems: double-targeted $\mathrm{pH}$-responsive pharmaceutical nanocarriers Bioconjug Chem. 2006;17(4):943-949.

27. Liu J, Jiang X, Xu L, Wang X, Hennink WE, Zhuo R. Novel reduction-responsive cross-linked polyethylenimine derivatives by click chemistry for nonviral gene delivery. Bioconjug Chem. 2010;21(10): 1827-1835.

28. Peng Q, Hu C, Cheng J, Zhong Z, Zhuo R. Influence of disulfide density and molecular weight on disulfide cross-linked polyethylenimine as gene vectors. Bioconjug Chem. 2009;20(2):340-346.

29. Peng Q, Zhong Z, Zhuo R. Disulfide cross-linked polyethylenimines (PEI) prepared via thiolation of low molecular weight PEI as highly efficient gene vectors. Bioconjug Chem. 2008;19(2):499-506.

30. Son S, Singha K, Kim WJ. Bioreducible BPEI-SS-PEG-cNGR polymer as a tumor targeted nonviral gene carrier. Biomaterials. 2010;31(24):6344-6354.

31. Sun YX, Zeng X, Meng QF, Zhang XZ, Cheng SX, Zhuo RX The influence of RGD addition on the gene transfer characteristics of disulfide-containing polyethyleneimine/DNA complexes. Biomaterials. 2008;29(32):4356-4365.

32. Takae S, Miyata K, Oba M, et al. PEG-detachable polyplex micelles based on disulfide-linked block catiomers as bioresponsive nonviral gene vectors. J Am Chem Soc. 2008;130(18):6001-6009.

33. Abdullah-Al-Nahain, Lee H, Lee YS, Lee KD, Park SY. Development of disulfide core-crosslinked pluronic nanoparticles as an effective anticancer-drug-delivery system. Macromol Biosci. 2011;11(9): 1264-1271.

34. Gosselin MA, Guo W, Lee RJ. Efficient gene transfer using reversibly cross-linked low molecular weight polyethylenimine. Bioconjug Chem. 2001;12(6):989-994.

35. Yu H, Russ V, Wagner E. Influence of the molecular weight of bioreducible oligoethylenimine conjugates on the polyplex transfection properties. AAPS J. 2009;11(3):445-455.

36. Ma N, Li Y, Xu H, Wang Z, Zhang X. Dual redox responsive assemblies formed from diselenide block copolymers. J Am Chem Soc. 2010;132(2):442-443. 
37. Xue Z, Kwong DWJ, Xue LW, Liu Q, Hou AX, Wong WK. Synthesis of novel diselenide-linked porphyrin dimers under phase-transfer catalysis condition and their interactions with DNA. Chem Biodivers. 2009;6(7):1131-1143.

38. Koch T, Suenson E, Henriksen U, Buchardt O. The oxidative cleavability of protein cross-linking reagents containing organoselenium bridges. Bioconjug Chem. 1990;1(4):296-304.

39. Saovapakhiran A, D'Emanuele A, Attwood D, Penny J. Surface modification of PAMAM dendrimers modulates the mechanism of cellular internalization. Bioconjug Chem. 2009;20(4):693-701.

40. Nie Y, Gunther M, Gu Z, Wagner E. Pyridylhydrazone-based PEGylation for $\mathrm{pH}-\mathrm{reversible} \mathrm{lipopolyplex} \mathrm{shielding.} \mathrm{Biomaterials.}$ 2011;32(3):858-869.
41. Kumbhare LB, Jain VK, Phadnis PP, Nethaji M. Palladium(II) and platinum(II) 2-(methoxycarbonyl)ethylselenolates: synthesis, spectroscopy, structures and their conversion into metal selenide. J Organomet Chem. 2007;692(7):1546-1556.

42. Ma N, Xu H, An L, Li J, Sun Z, Zhang X. Radiation-sensitive diselenide block co-polymer micellar aggregates: toward the combination of radiotherapy and chemotherapy. Langmuir. 2011;27(10):5874-5878.

43. Cha W, Meyerhoff ME. Catalytic generation of nitric oxide from S-nitrosothiols using immobilized organoselenium species. Biomaterials. 2007;28(1):19-27.

44. Nie Y, Yuan WM, Gong T, Lu J, Fu Y, Zhang ZR. Investigation on characterization and transfection of a novel multi-polyplex gene delivery system. J Appl Polym Sci. 2007;106(2):1028-1033. 


\section{Supplementary figures}

A
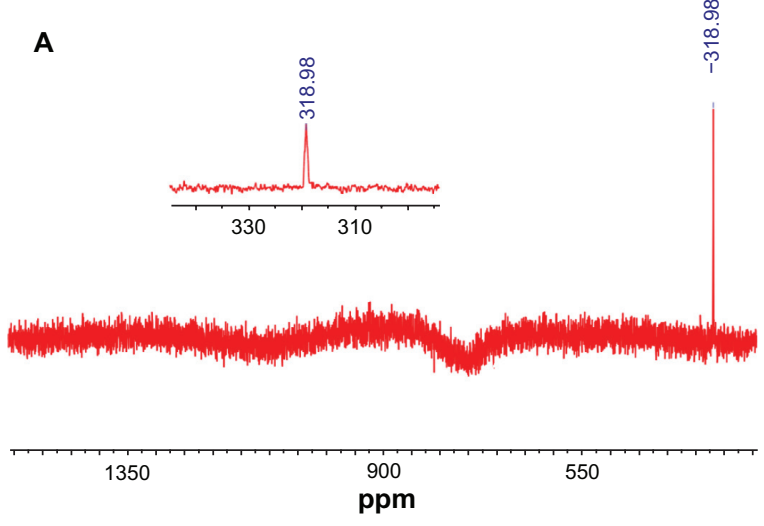

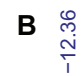
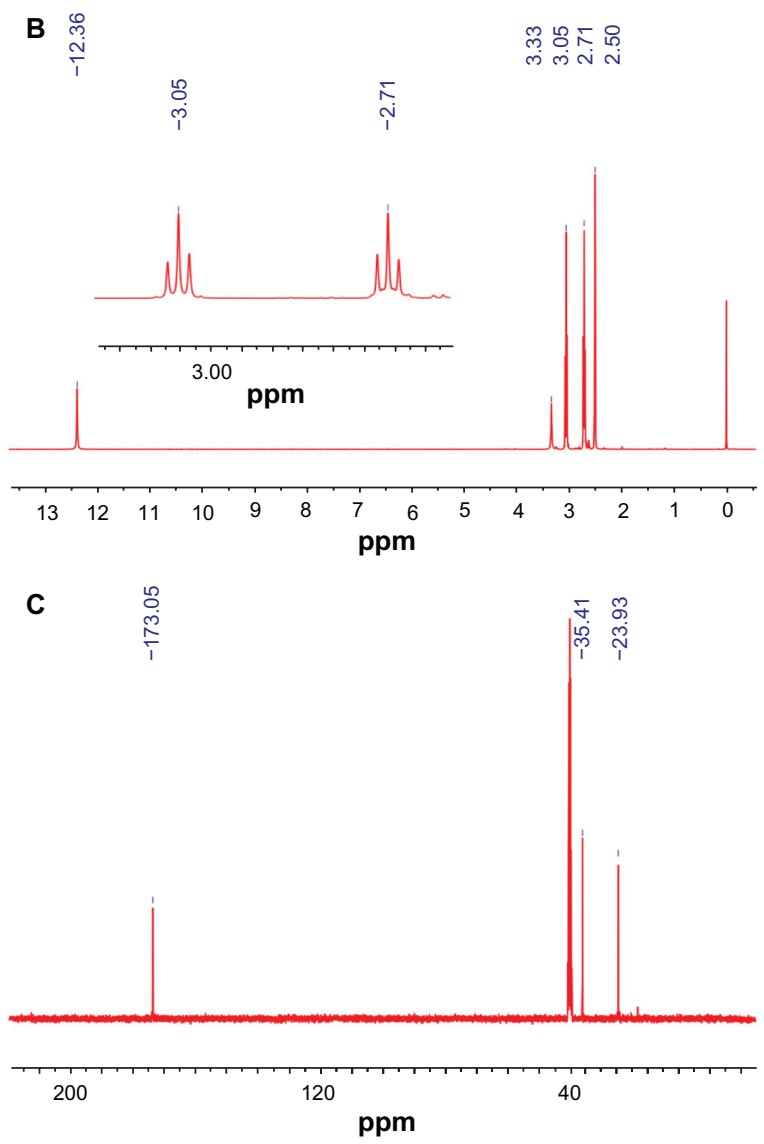

Figure SI NMR spectrum of DSeDPA. (A) ${ }^{77}$ Se NMR spectrum; (B) 'H NMR spectrum; (C) ${ }^{13} \mathrm{C}$ NMR spectrum.

Abbreviation: DSeDPA, 3, 3'-Diselanediyldipropanoic acid; NMR, nuclear magnetic resonance.

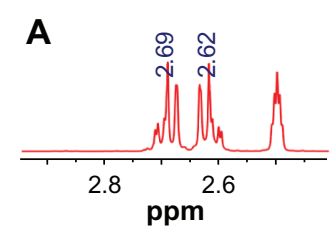

ฮิ ญิ
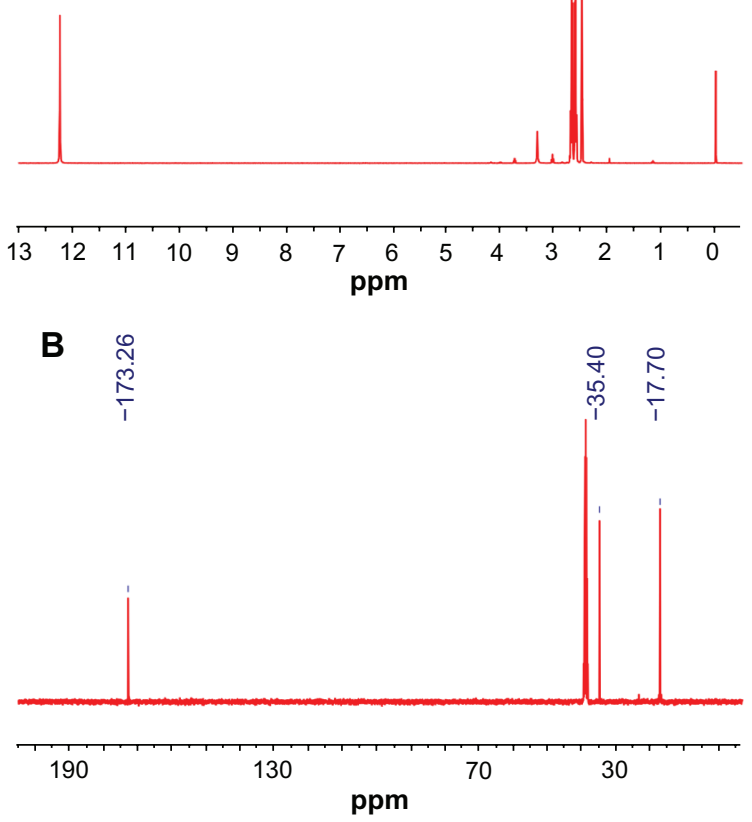

Figure S2 NMR spectrum of SeDPA. (A) 'H NMR spectrum; (B) ${ }^{13} \mathrm{C}$ NMR spectrum. Abbreviation: SeDPA, 3, 3'-selenodipropanoic acid; NMR, nuclear magnetic resonance.

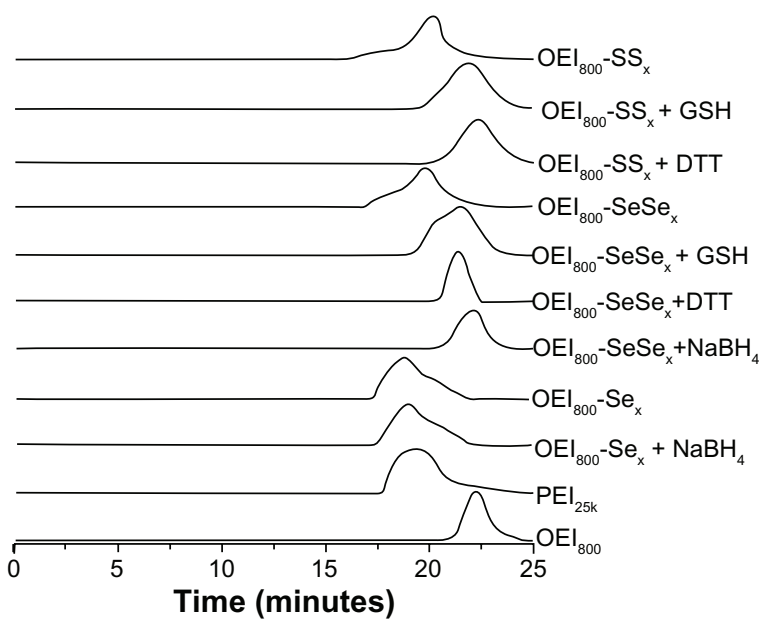

Figure S3 GPC traces of $\mathrm{OEI}_{800}-\mathrm{SS}_{x}, \mathrm{OEI}_{800}-\mathrm{SeSe}_{x}, \mathrm{OEI}_{800}-\mathrm{Se}_{x}$ and the $\mathrm{OEI}_{800}$ derivatives in the absence or presence of reduction treatment.

Abbreviations: GPC, gel permeation chromatography; OEl, oligoethylenimine; DTT, I,4-dithiothreitol; GSH, glutathione. 

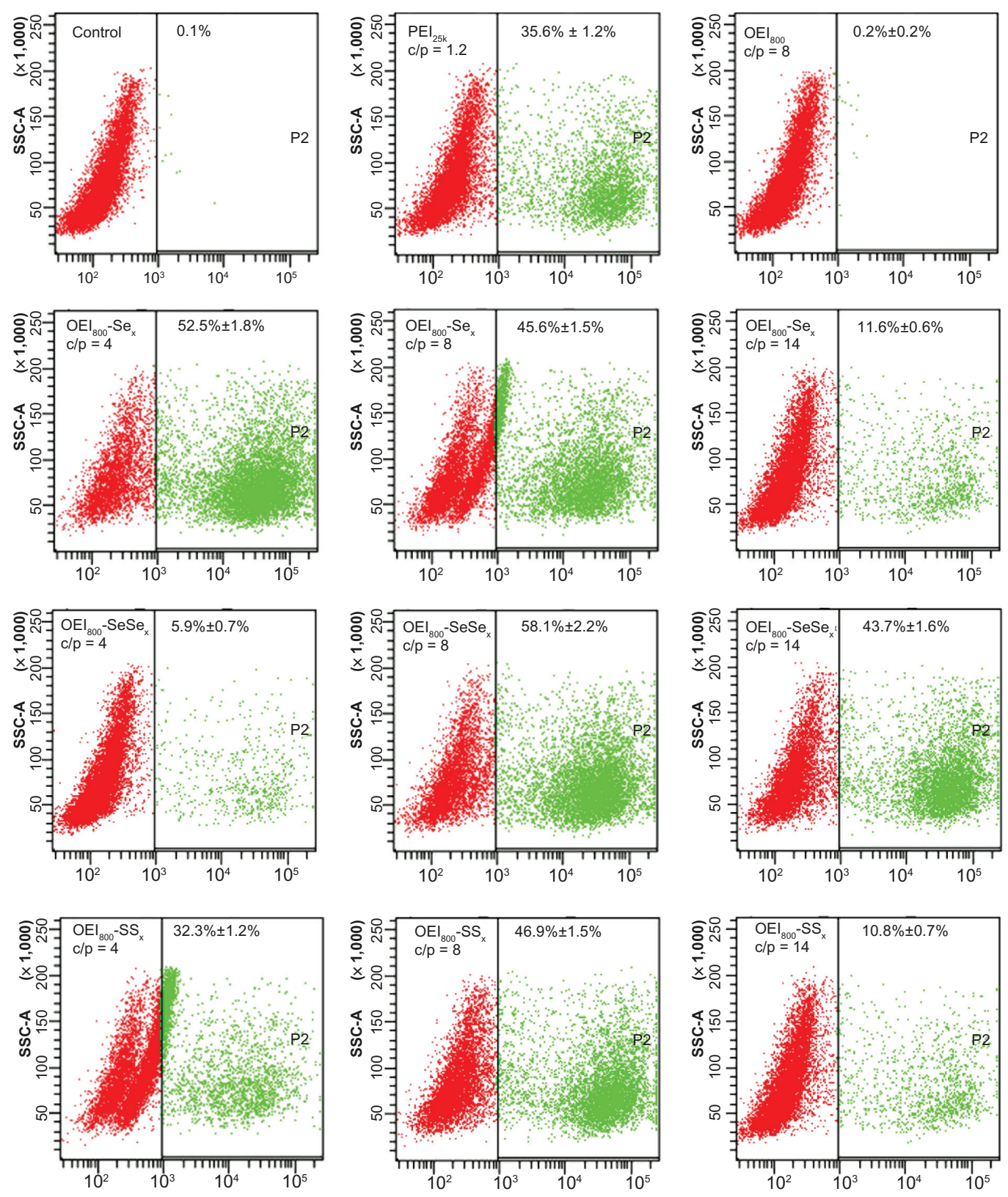

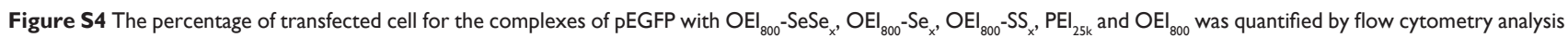
in BI6FI0 cell lines at 48 hours.

Note: $\mathrm{n}=3$.

Abbreviations: pEGFP, enhanced green fluorescent protein encoding plasmid; PEI, polyethylenimine; OEl, oligoethylenimine.

\section{Publish your work in this journal}

The International Journal of Nanomedicine is an international, peerreviewed journal focusing on the application of nanotechnology in diagnostics, therapeutics, and drug delivery systems throughout the biomedical field. This journal is indexed on PubMed Central, MedLine, CAS, SciSearch $\AA$, Current Contents $₫ /$ Clinical Medicine,
Journal Citation Reports/Science Edition, EMBase, Scopus and the Elsevier Bibliographic databases. The manuscript management system is completely online and includes a very quick and fair peer-review system, which is all easy to use. Visit http://www.dovepress.com/ testimonials.php to read real quotes from published authors. 